\title{
Reconnaissance geology and geophysics of the Mercurio structural dome, Chihuahua, Mexico
}

\author{
José Jorge Aranda-Gómez ${ }^{1, *}$, Vsevolod Yutsis ${ }^{2}$, Edgar Juárez Arriaga ${ }^{3}$, \\ Carlos Ortega-Obregón ${ }^{1}$, Norma González-Cervantes ${ }^{3}$, \\ Gabriel Chávez-Cabello ${ }^{4}$, César Francisco Ramírez-Peña ${ }^{4}$, \\ and David Ernesto Torres-Gaytán²
}

\author{
${ }^{1}$ Centro de Geociencias, Universidad Nacional Autónoma de México, Campus Juriquilla, 76230 Querétaro, Qro., Mexico. \\ ${ }^{2}$ División de Geociencias Aplicadas, Instituto Potosino de Investigación Científica y Tecnológica, San Luis Potosí, S.L.P., Mexico. \\ ${ }^{3}$ Posgrado en Ciencias de la Tierra, Centro de Geociencias, Universidad Nacional Autónoma de México, Querétaro, Qro., Mexico. \\ ${ }^{4}$ Facultad de Ciencias de la Tierra, Universidad Autónoma de Nuevo León, Linares, N.L., Mexico. \\ *jjag@geociencias.unam.mx
}

\begin{abstract}
The Mercurio structural dome is a poorly exposed and complex structure located in the transitional region between the Coahuila Calcareous Platform and the San Pedro El Gallo sector of the Sierra Madre Oriental, Mexico. It is located in the State of Chihuahua, close to the limits with Coahuila and Durango, Mexico. The dome is a circular structure, $\sim 16 \mathrm{~km}$ in diameter, that can be seen in airphotos, satellite images, and shaded relief maps, but that has a subtle topographic expression on the ground. As seen in the field, the most conspicuous topographic features in the area are several hills with the morphology of volcanic necks that rise up to $250 \mathrm{~m}$ above the surrounding terrain. The deformation fringe of the dome is a series of cuesta-like low hills, less than $30 \mathrm{~m}$ high, where a poorly lithified volcano-sedimentary succession (litharenites, polymictic conglomerates, and ignimbrites) is almost completely masked by desert pavement, which is mainly constituted by well-rounded calcareous clasts derived from the Mesozoic sedimentary marine rocks and by less abundant Paleogene volcanic rocks exposed in the region. Inside the dome the following units are exposed: 1) the pre-volcanic basement in a NW-trending, upright, open anticline developed in limestone of the Aurora Formation, 2) a series of hills where is exposed a succession of epiclastic and volcanic rocks, which are similar, in age and lithology, to some facies of the Ahuichila Formation, and 3) a NW-trending dike, exposed at Cerro Dinamita, which is interpreted as an offshoot of the buried subvolcanic body that created the dome. The deformation fringe around the buried intrusive has a quaquaversal array in the bedding and forms a simple monocline-like structure in the NE part of the dome. A set of SE- and NW-trending plunging folds forms the SE and SW portions of the dome, respectively. The NW part of the fringe is nearly completely masked by volcanic rocks, but there is a $\sim \mathrm{W}$ plunging syncline in the area.

Geophysical data show a broad gravimetric high in the region, and there is a distinct aeromagnetic anomaly inside the dome. The morphological expression of the dome lies just east of a NW-trending lineament
\end{abstract}

of gravity and magnetic anomalies, which may be the buried portion of a normal fault shown in geologic maps of the region northwest of the studied area. Another possible cause is an alignment of buried intrusive bodies suggested by the regional aeromagnetic data, a small diorite outcrop south of Sierra El Diablo, and presence of volcanic necks in the northern portion of Sierra Los Alamos. Available geological and geophysical information was used to model a near-surface, irregular intrusive body with variable magnetic susceptibilites. This variation in susceptibilities is consistent with observed differences in rock composition in the exposed volcanic rocks and with evidence that the structure was formed by a bimodal (andesite-rhyolite) magmatic system where mixing/mingling occurred.

As a whole, the set of structures is interpreted as a dome formed by forceful magma injection into a previously folded Paleogene volcanosedimentary succession. $\mathrm{U}-\mathrm{Pb}$ zircon ages were used to bracket the age of the deformation pulses registered in the rocks. Litharenites from the deformed volcano-sedimentary succession yielded an Ypresian zircon age of $\sim 51 \mathrm{Ma}$. A tilted, lithic-rich ignimbrite collected near the top of the exposed volcano-sedimentary succession has mean age of $46.4^{+0.8} /{ }_{-1.6} \mathrm{Ma}$, and the Cerro Dinamita dike has a mean age of $29.37 \pm 0.24 \mathrm{Ma}$. Thus, the youngest pulse of Laramide deformation in the area is younger than $\sim 46 \mathrm{Ma}$ and the re-folding, associated with emplacement of the dome occurred at $\sim 29 \mathrm{Ma}$.

Detrital zircon $\mathrm{U}-\mathrm{Pb}$ ages from Mercurio sandstones suggest dominant sediment sources from plutonic and/or volcanic rocks exposed along western Mexico. Likely subordinate sources are Mesozoic sedimentary rocks in northern and central Mexico. Distribution of detrital zircon $\mathrm{U}-\mathrm{Pb}$ ages in the studied samples is similar to that documented in sandstones of the Difunta Group at the Parras and La Popa basins, except that older grains $(>1.0 \mathrm{Ga})$, documented in the clastic rocks of these basins, are scarce in the sandstones of the Mercurio area.

Key words: structural dome; forceful injection; geophysical modeling; magma mixing and mingling; Ahuichila Formation; Sierra Madre Occidental; Coahuila Calcareous Platform; Mexico. 


\section{RESUMEN}

El domo estructural de Mercurio es una estructura compleja pobremente expuesta, que se ubica en la transición entre la Plataforma Carbonatada de Coahuila y el Sector San Pedro El Gallo de la Sierra Madre Oriental. La estructura está en el Estado de Chihuahua, cerca de los límites con Coahuila y Durango, México. El domo es un rasgo circular, de unos $16 \mathrm{~km}$ de diámetro, que puede verse en fotografías aéreas, en imágenes de satélite y en mapas de relieve sombreado, pero que en el campo es difícil de distinguir por su expresión topográfica sutil. Los rasgos topográficos más conspicuos en el campo son cerros con la morfología característica de cuellos volcánicos, que se elevan hasta $250 \mathrm{~m}$ por encima del terreno que las circunda. La aureola de deformación del domo está representada por una serie de colinas bajas con forma de cuestas, de menos de $30 \mathrm{~m}$ de alto, en donde una sucesión volcano-sedimentaria (litarenitas, conglomerados polimícticos e ignimbritas) pobremente litificada está casi por completo enmascarada por pavimento del desierto, constituido por clastos de caliza bien redondeados, derivados principalmente de las rocas marinas del Mesozoico y en menor proporción de las rocas volcánicas del Paleogeno expuestas en la región. En el interior del domo afloran: 1) rocas del basamento prevolcánico en un anticlinal abierto, vertical, desarrollado en caliza de la Formación Aurora, 2) un conjunto de colinas en donde está expuesta una sucesión formada por rocas epiclásticas y volcánicas, similar en edad y litología a algunas facies de la Formación Ahuichila, y3) un dique con rumbo NW, expuesto en el Cerro Dinamita, que es considerado un apéndice del cuerpo subvolcánico que originó al domo. La aureola de deformación alrededor del intrusivo subvolcánico causó un arreglo radial centrífugo en las capas sedimentarias y forma una estructura simple, tipo monoclinal, en la parte NE del domo. Un conjunto de pliegues con inmersiones al SE y NW forman las porciones SE y SW del domo, respectivamente. La porción NW de la aureola está casi completamente enmascarada por rocas volcánicas, pero en esa área se distinguió al menos un sinclinal con inmersión aproximadamente al $W$.

La información geofísica muestra un amplio alto gravimétrico en la región y existe una anomalía aeromagnética bien definida en el interior del domo. La expresión geomorfológica del domo yace justo al este de un lineamiento definido por anomalías gravimétricas y aeromagnéticas, que pueden reflejar la parte sepultada de una falla normal con rumbo NW, que se muestra en mapas geológicos de la región, al NW del área de estudio. Otra causa posible es un alineamiento de cuerpos intrusivos no expuestos sugeridos por la información aeromagnética regional, un afloramiento de diorita pequeño al sur de la Sierra El Diablo y por la presencia de cuellos volcánicos en la parte septentrional de la Sierra Los Alamos. La información geológica y geofísica se empleó para elaborar el modelo de un cuerpo intrusivo somero, formado por rocas con susceptibilidades magnéticas variables. Los cambios en susceptibilidad son consistentes con las rocas volcánicas expuestas en la superficie y con la evidencia de que la estructura fue formada por un sistema magmático bimodal (andesita-riolita) en donde hubo mezcla física y química de magmas.

En su conjunto, la estructura es interpretada como un domo formado por inyección forzada de más de un tipo de magma en una sucesión volcano-sedimentaria del Paleógeno, previamente plegada. Edades $U-P b$ en circones fueron empleadas para establecer los límites temporales de la edad de los pulsos de deformación registrados en las rocas. Una litarenita de la sucesión volcano-sedimentaria deformada dio una edad ypresiana de $51 \mathrm{Ma}$. Una ignimbrita rica en líticos de la parte superior de la porción expuesta de la sucesión volcano-sedimentaria tiene una edad media de 46.4 +0.8/-1.6 Ma, y el dique del Cerro Dinamita tiene una edad media de $29.37 \pm 0.24 \mathrm{Ma}$. Por tanto, la edad del pulso de deformación laramídica más joven en el área debe de ser más joven que $46 \mathrm{Ma}$, y el replegamiento causado por el emplazamiento del domo sucedió $\sim 29 \mathrm{Ma}$.

Las edades $U-P b$ en circones detríticos en muestras de Mercurio su- gieren que las fuentes de estos granos son rocas plutónicas y/o volcánicas expuestas en el occidente de México. Otras fuentes potenciales, menos importantes, son rocas sedimentarias mesozoicas del norte y centro de México. La distribución de las edades U-Pb en granos de circón detrítico de las muestras de arenisca estudiadas es similar a las documentadas en el Grupo Difunta en las cuencas de Parras y La Popa, excepto que las areniscas del área de Mercurio contienen una menor cantidad de circones viejos (>1.0 Ga) en comparación con las areniscas de las cuencas mencionadas.

Palabras clave: domo estructural; inyección forzada; modelado geofísico; mezcla física y química de magmas; Formación Ahuichila; Sierra Madre Occidental; Plataforma Calcárea de Coahuila; México.

\section{INTRODUCTION}

One of the most important tectonic events in central and northern Mexico during the Cenozoic was the transition from regional shortening that caused the Sierra Madre Oriental folding and thrusting to volcanism and extension related first to the Sierra Madre Occidental and later to Basin and Range tectonics. The stratigraphic record of this change in many places is marked by the presence of sandstone-rich fluvial and/or deltaic deposits, where red beds may be a conspicuous component. These sediments lie between folded and thrusted Mesozoic marine sediments and thick successions of orogenic calc-alkaline volcanic rocks (e.g., Schulze, 1953; Edwards, 1955; Aranda-Gómez and McDowell, 1998). In those places where it can be seen, the contact relation of the continental red beds with the underlying rocks is always a marked angular unconformity. In some localities, such as in the Guanajuato, Pinos, and Zacatecas mining districts (Figure 1a), the red beds appear to be undeformed but tilted together with the overlying volcanic successions. Elsewhere, such as in the Transverse Ranges of the Sierra Madre Oriental (i.e., Sector Transversal de Parras: Eguiluz de Antuñano et al., 2000), the red bed successions (i.e., Ahuichila Formation in that region) are gently folded, with a structural style that contrasts with the intense deformation seen in the underlying Mesozoic marine sediments exposed in the same areas (e.g., Rogers et al., 1961; Martínez-Reyes, 1989). Folded structures in Ahuichila rocks at its type locality (Figure 1b) have been attributed by Tardy (1980) to a late pulse (Miocene) of contractional deformation, which produced broad, gentle "plis $d u$ fond". Regional trend of post-Ahuichila folds in the Transverse Ranges is NNW-SSE (Martínez-Reyes, 1989)

Folding of Eocene-Oligocene volcano-sedimentary successions in the region immediately west of the Coahuila Calcareous Platform (Figure 1b) has been documented in recent years. Some of those folds, such as those in the sierras Aguachile and La Herradura synclines (Figure 1b), have been interpreted as products of transtensional reactivation of a large basement structure (i.e., the San Marcos fault Figure 2a), during Neogene periods of crustal extension (ArandaGómez, 2005). Others, like those exposed at the Manuel Benavides area (Figure 2a), are explained either as deformation caused by tumescence in a caldera system (McDowell, 2010) or as products of left-lateral displacement along a basement fault (i.e., La Babia fault; Flotte et al., 2008). The syncline of Sierra Cuesta del Infierno, immediately west of the Plomosas uplift (Figure 2a), is regarded as a fault-bend fold caused by the reactivation of the Solís thrust during a period of extension in the region (Oviedo-Padrón et al., 2010).

Unconsolidated gravel deposits, almost exclusively made of calcareous clasts derived from Mesozoic marine sediments, and tilted 40-70 occur at Cerro El Jabalí, near the Camargo volcanic field (Figures $1 \mathrm{~b}$ and $2 \mathrm{a}$ ), about $120 \mathrm{~km} \mathrm{N45W}$ of Mercurio, in a rollover 
anticline, which suggests that they are a growth deposit associated to the activity of a large normal fault (Aranda-Gómez et al., 2001). These Paleogene gravels are intruded by a $46 \mathrm{Ma}$ old andesitic sill and, in places they are partially covered by undeformed Eocene volcanic rocks (Aranda-Gómez et al., 2003).

Extension-related folding of volcanic rocks (andesite, Ar-Ar 33.5 Ma Aranda-Gómez et al., 2005) at La Herradura syncline also affected gravel deposits made of calcareous clasts, but with a small amount of volcanic fragments. Stratigraphic and cross-cutting relations around the Camargo volcanic field suggest that local shortening, both at Aguachile and La Herradura, occurred in the 12 - $5 \mathrm{Ma}$ lapse.

The age of Ahuichila Formation near the Sierra San Julián (Figure $1 b$ ) is bracketed between 40 and $32 \mathrm{Ma}$ (U-Pb zircon ages in a tuffaceous sandstone and in an interbedded lava flow: Ramírez-Peña, 2017). In that locality the red beds are folded into a NW-trending open syncline and the deformation is attributed to a late pulse of thick-skinned deformation (a drag fold related with the Norias fault, which is a high angle reverse fault at the NE border of the San Julián block) in that area, located just south of the central part of the Transverse Ranges (Ramírez-Peña and Chávez-Cabello, 2017).

Domes formed by underlying laccoliths or stocks produced by forceful injection of magma have been described in several areas in central and northern Mexico, such as in the Candela-Monclova Intrusive Belt (Chávez-Cabello, 2005) and in the transitional zone between the Transverse Ranges and the Mesa Central (Ramírez-Peña,
2017). Age relations of these structures with respect to Sevier and/or Laramide orogenies and to Basin and Range extension (Figure $2 \mathrm{~b}$ ) are variable. The complexity of the structural relations between the domes and their country rocks is also variable, as in some localities such as in Cerro Marcelinos (Figure 2a), in the Candela-Monclova Intrusive Belt, it appears to be simple, whereas in the post-tectonic plutons as in the Providencia intrusive body (Figure 2a) is quite complex with numerous, structurally discordant, fold axes around the pluton (Chávez-Cabello, 2005). Whether these complex relations are produced only by modification of older folds, or are caused by local deformation caused by magma emplacement is a fact that has to be investigated in each pluton.

Based on satellite image interpretation we identified a previously unknown region, west of Sierra Tlahualilo (Figure 1b) where there is evidence of post-Laramide folding of gravel and volcanic deposits of unknown age and origin. This new locality is near the western border of the Coahuila Calcareous Platform (Figure 2a). Near the region where the Chihuahua, Coahuila and Durango state limits converge (Figure 1c) exists a subtle, circular structure, nearly $16 \mathrm{~km}$ in diameter, where sediments are folded into a complex domal structure. Inside, and near the outer border of the dome are exposed several volcanic necks and dikes of intermediate to felsic composition (Aranda-Gómez et al., 2016). We refer to this structure as the Mercurio structural dome (MD: Figure $1 \mathrm{~b}$ and $2 \mathrm{a})$, as near its northern border is a small ranch named Mercurio in the INEGI (2008) topographic sheet.

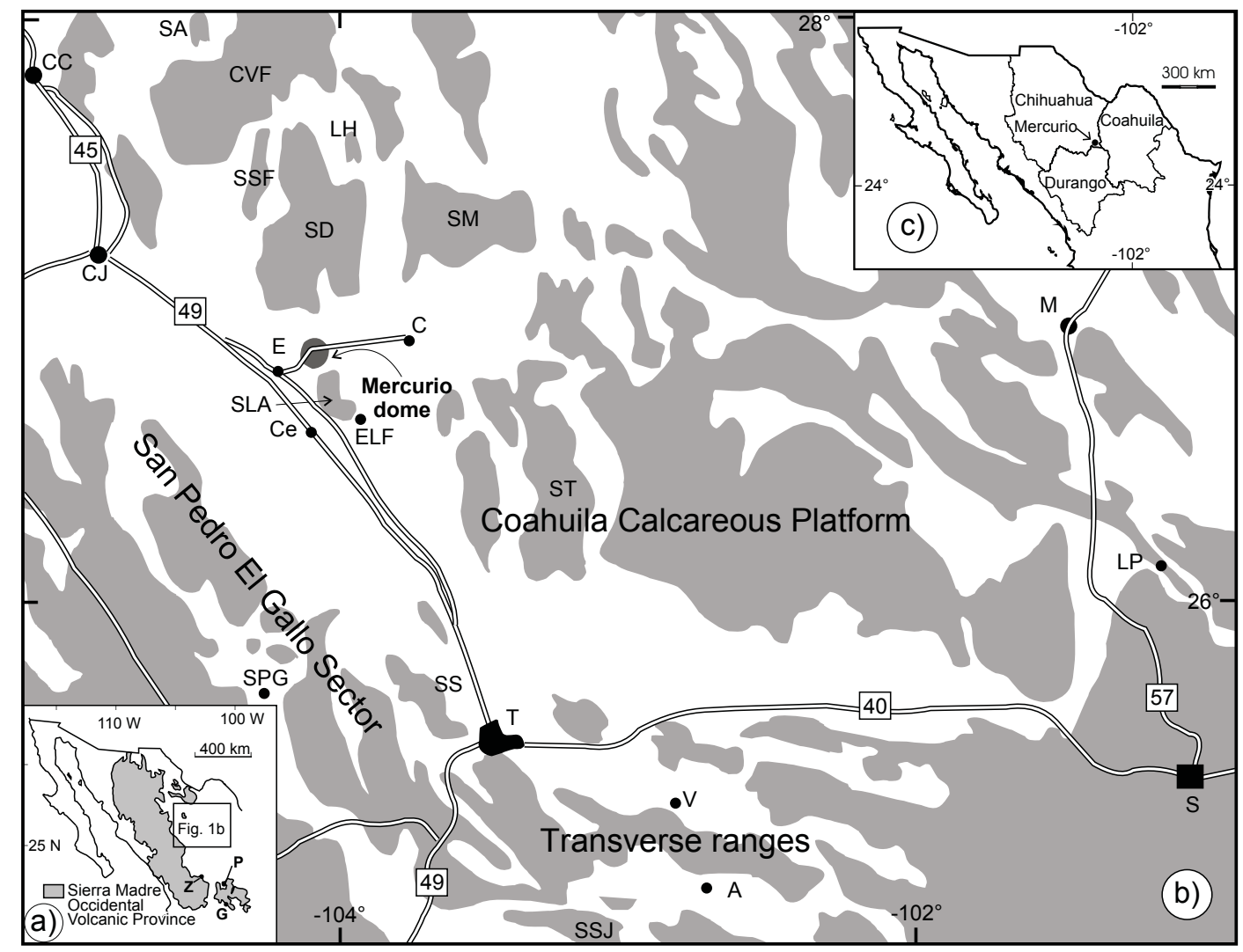

Figure 1. Location and index maps. a) Present day distribution of rocks of the Sierra Madre Occidental volcanic province. Note that the there are two regions where remnants of the volcanic field are considerably wider. Mining districts: $G=$ Guanajuato, $P=$ Pinos, and $Z=$ Zacatecas. $b$ ) Mountainous regions (grey) in northcentral Mexico: the Mercurio structural dome is located south of Sierra El Diablo (SD). c) Political division. Other localities mentioned in the text: A = Bajío de Ahuichila, $\mathrm{C}=$ Carrillo, $\mathrm{CC}=$ Ciudad Camargo, $\mathrm{Ce}=$ Ceballos, $\mathrm{CJ}=$ Ciudad Jiménez, $\mathrm{CVF}=$ Camargo volcanic field, $\mathrm{E}=\mathrm{Escalón}, \mathrm{ELF}=\mathrm{Ejido} \mathrm{La}$ Flor, $\mathrm{LH}=\mathrm{La}$ Herradura, LP = La Popa, M = Monclova, S = Saltillo, SA = Sierra Aguachile, SLA = Sierra Los Álamos, SM = Sierra Mojada, SPG = San Pedro El Gallo, SS= Sierra de Sarnoso, SSF = Sierra San Francisco, SSJ = Sierra San Julián, ST = Sierra Tlahualilo, T = Torreón, V = Viesca. 


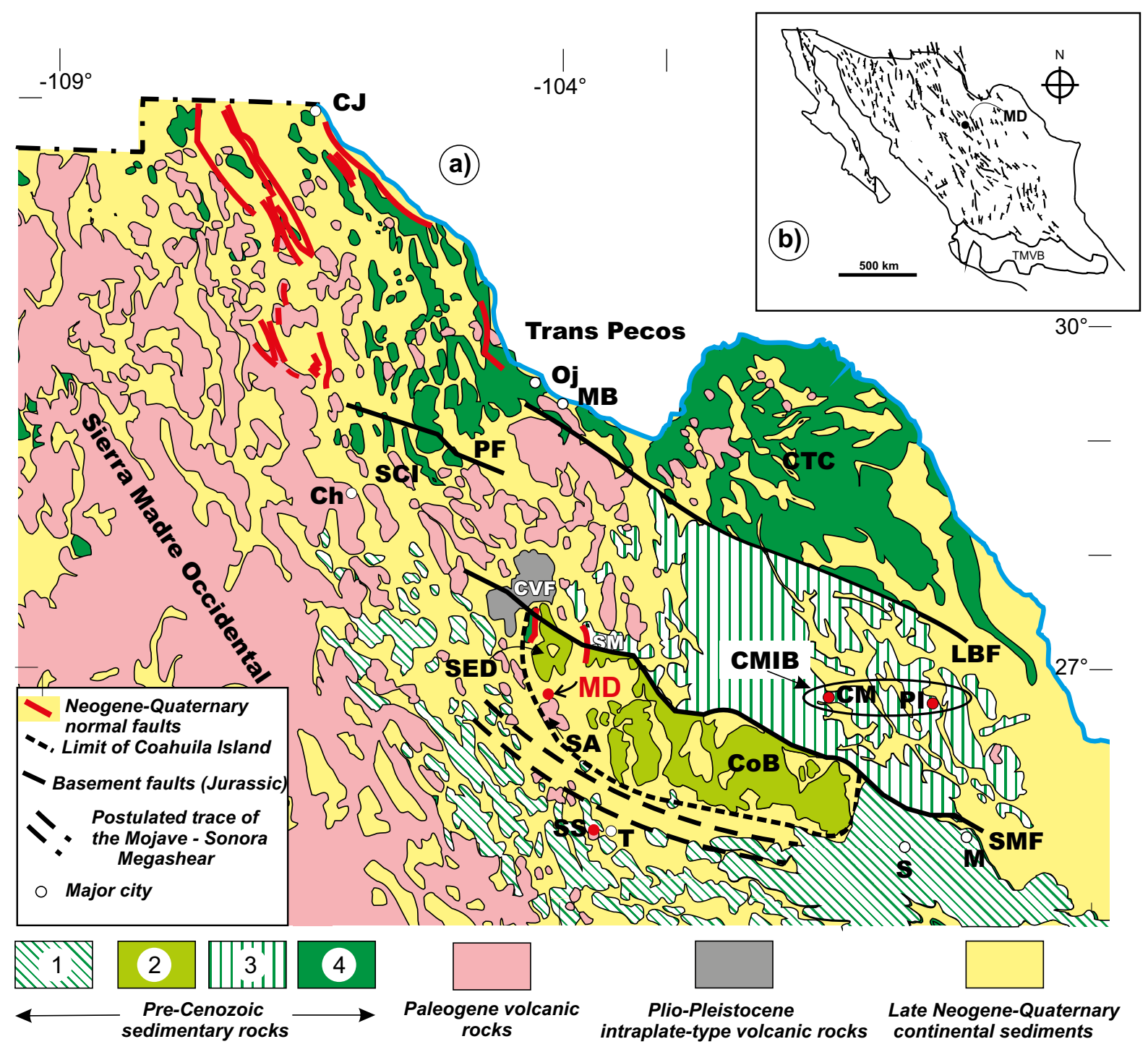

Figure 2. Regional geological setting of the Mercurio structural dome (MD). The study area is close to the transition between two important paleogeographic features. East of the dome is the Coahuila Calcareous Platform and west of it the sedimentary successions were accumulated in the Mexican Sea (Haenggi, 2005). Near the MD exist extensive outcrops of Paleogene volcanic rocks of the Sierra Madre Occidental volcanic province, which is considerably wider in that region; these volcanic rocks extend all the way to Trans Pecos (Texas). Pre-Cenozoic sedimentary marine successions are all shown in different shades or patterns of green, depending on the basin where they accumulated. These basins are 1. Mexican Sea, 2. Coahuila Calcareous Platform, 3. Sabinas basin, and 4. El Burro-Peyotes península. Broadly speaking, each succession has different structural styles, a fact noted by Kellum et al. (1936). These structural domains appear to reflect the influence that different lithologies in the sedimentary successions exerted on the deformation during the Sevier(?) and/or Laramide orogenies in the area. Inset $b$ shows the extent of the southern Basin and Range province in Mexico (Henry and Aranda-Gómez, 1992). TMVB = Trans Mexican Volcanic Belt. The location of the MojaveSonora megashear near Mercurio is after McKee et al. (1990). Other important basement structures are: LBF $=$ La Babia fault, PF = Plomosas fault, and SMF = San Marcos fault. Other acronyms: $\mathrm{Ch}=$ Chihuhua, $\mathrm{CJ}=$ Ciudad Juárez, $\mathrm{CM}=$ Cerro Marcelinos, $\mathrm{CMIB}=$ Candela - Monclova intrusive belt, $\mathrm{CTC}=\mathrm{Coahuila}-\mathrm{Texas}$ craton, $\mathrm{CoB}=$ Coahuila Block, $\mathrm{CVF}=$ Camargo volcanic field, $\mathrm{M}=$ Monterrey, $\mathrm{MB}=$ Manuel Benavides, $\mathrm{Oj}=\mathrm{Ojinaga}, \mathrm{PI}=\mathrm{Providencia}$ intrusive body, $\mathrm{S}=\mathrm{Saltillo}$, $\mathrm{SA}=$ Sierra Los Alamos, SM = Sierra Mojada, SCI = Sierra Cuesta del Infierno, SED = Sierra El Diablo, SS = Sierra Sarnoso, T = Torreón.

The goals of this contribution are to document the Mercurio domal structure, establish the age of the rocks that form the dome and discuss the possible role of regional shortening (i.e., Laramide) and magmatic activity in its formation. The Mercurio structural dome is located in the Chihuahuan desert, and the presence of eolian deposits and desert pavement (Figure 3), together with shallow river incision, as the region is in an endorheic basin, makes it difficult to study the poorly- to moderately-consolidated clastic and interlayered volcanic deposits involved in the deformation. In most places visited, the deformed volcano-sedimentary deposits form small asymmetric cuestas, generally no more than $20-30 \mathrm{~m}$ high. These cuestas allow inferring the general attitude of the rocks hidden by desert pavement, as the dip direction invariably lies on the gentler, generally flat side of the cuestas, but actual exposures of the geologic successions are rare.

Geological information about the Mercurio structural dome is scant and of regional nature. Exposure is poor in critical parts in the deformation fringe of the structure and a large part of the structure is buried under volcanic rocks. Therefore, it is believed that complementary geophysical data may be important to understand the structure. Although we did not collect geophysical data in the field, available 
high resolution satellite information (gravity) and aeromagnetic data obtained from the Servicio Geológico Mexicano was processed and used to model the hidden intrusive underneath the dome.

\section{REGIONAL GEOLOGIC SETTING REVIEW}

The Mercurio region is located in the southeastern part of Chihuahua state (Figure 1c). This region is in the transition between the western border of the Cretaceous Coahuila Calcareous Platform and the Sierra Madre Occidental volcanic province (Eocene-Oligocene). Just about the latitude of Mercurio (Figures 1a and 2a) begins a region where the Sierra Madre Occidental is significantly wider as its volcanic rocks (including near-vent facies) occur as isolated outcrops all the way to Trans-Pecos, Texas (Cameron et al., 1980).

The city of Torreón is located approximately $170 \mathrm{~km}$ to the S40E of Mercurio dome, where the general E-W trending Laramide structures change to N30W (i.e., the Torreón recess; Figure 2a). This NW orientation is generally shown by the scant folded sediments exposed in the Mercurio Area.

The folding style at the Coahuila platform is notoriously different from that present in the Transverse Ranges of the Sierra Madre Oriental, between Saltillo and Torreón (Figure 1b), and also from that in the region west and northwest of Torreón (i.e., San Pedro El Gallo sector: Eguiluz de Antuñano et al, 2000). Major structures inside the Coahuila platform usually are broad, gentle, N- to NW-trending, double plunging folds. Almost perpendicular to major structures are smaller cross-folds, which are believed to reflect buried topographic structures or faults in the basement rocks (e.g., Kellum et al., 1936). The Laramide deformation is tighter in the Transverse Ranges. Folds there have ESE-WNW trends, and anticlines are commonly overturned or recumbent, with steeper northern flanks (Eguiluz de Antuñano et al., 2000). Fold widths in the Transverse Ranges vary from a few hundred meters to a few kilometers. Thrust faults are common in the region and the frontal thrust (i.e., the Parras Nappe: Tardy, 1980) overrides

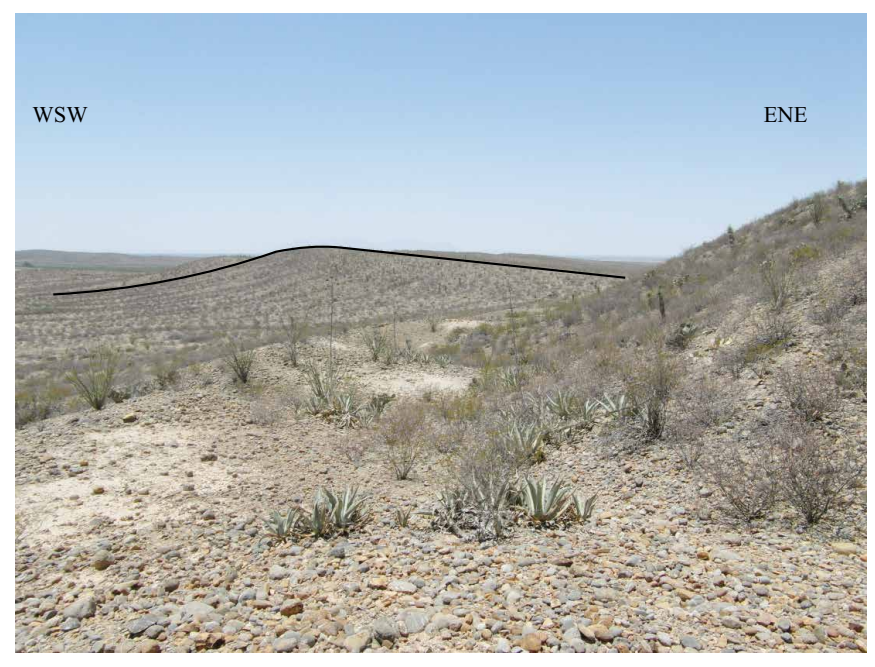

Figure 3. A large portion of the surface geology is hidden under a thin, but continuous cover of desert pavement, composed mainly by well-rounded clasts (pebbles to small cobbles) mainly derived from Mesozoic sedimentary rocks and a small proportion of Cenozoic(?) volcanic rocks. The foreground shows desert pavement. Near the horizon, gently inclined cuestas indicate that the succession is tilted to the ENE: the asymmetry in profile of the cuestas allow to infer the dip direction of the underlying layers in the volcano-sedimentary succession. sediments of the Coahuila Calcareous Platform (Martínez-Reyes, 1989) near Viesca (Figure 1b). Laramide structures in the San Pedro El Gallo area (Figure 1b) are complex, narrow and elongated, with a N40W trend; anticlines have the form of fault propagation folds with vergence to the northeast. These broad changes in the structural styles were produced by the variation in the mechanical properties - such as strength (viscosity) difference among strata with different lithology and/or thickness - of the sedimentary successions accumulated atop the Coahuila Peninsula and those deposited at the bottom of the Mexican Sea and other sedimentary basins (Haenggi, 2002, Araujo-Mendieta and Arenas-Partida, 1986). The Mercurio structural dome is near the region where platform sediments grade into sediments of the Mexican Sea (Figure 2), probably near the border of a Jurassic pull-apart basin (Haenggi, 2002).

Outcrops of Cenozoic volcanic rocks related to the Sierra Madre Occidental volcanic province are common in the Mercurio region. South of the dome is a broad area covered by a layered volcanic succession that is shown in published geologic maps of areas located in the Chihuahua-Coahuila-Durango region, as Sierra Los Alamos (Barbosa-Luna et al., 1998). In the area between the southern end of Sierra El Diablo and Sierra Los Alamos (Figure 2a) there are several isolated mountains with the characteristic morphology of necks exposed in deeply eroded volcanoes; at least one of them is inside the dome (Cerro Dinamita: Figure 4). Likewise, in the same general area, Prian et al. (2000) reported the existence of a diorite outcrop, which probably belongs to another almost completely hidden intrusive body.

Sierra El Diablo (SED: Figure 2), located $20 \mathrm{~km}$ NW of Mercurio, is a broad open anticline formed in rocks of the Coahuila Calcareous Platform. The oldest rocks known in the region are exposed at its core in a small outcrop. They are continental volcanic rocks of uncertain age (Rb-Sr, two point isochron: $197 \pm 15 \mathrm{Ma}$ ) and origin (Nazas Fm or Las Delicias volcanic arc?), which are unconformably overlain by Aurora Formation limestone (Jones and McKee, 1987). On both sides of Sierra El Diablo are two branches of the $\sim \mathrm{N}-\mathrm{S}$-trending Bolsón de Mapimí (Figure 2a), which is a major Basin and Range structure between the Camargo volcanic field and Sierra Mojada (e.g., Aranda-Gómez et al., 2003). The western and eastern mountain fronts, respectively, of Sierra Mojada and Sierra San Francisco (Figure 1b), have low sinuosities, a feature that has been interpreted as evidence of late Cenozoic or Quaternary activity of the bounding normal faults (Aranda-Gómez et al., 2003; 2016).

A few tens of kilometers south and west of the Mercurio area is the probable zone of movement of the Mojave-Sonora megashear (Figure 2), a postulated major basement structure, which in the area is roughly parallel to the southern boundary of the Coahuila Platform (e.g., McKee et al.1990).

Finally, the Mercurio area is located above a PennsylvanianPermian continental boundary named the Ouachita-Marathon orogenic suture, which separates the North American craton from tectonostratigraphic terranes of Mexico with Gondwana affinities (Campa and Coney, 1983; Sedlock et al., 1993; Dickinson and Lawton, 2001; Keppie, 2004).

\section{LOCAL GEOLOGY}

\section{Physiography}

The Mercurio structural dome, as seen from the air, is an obvious, but subtle, nearly-circular structure $\sim 16 \mathrm{~km}$ in diameter (Figure 5 and 6). Its shape in plan view is defined by a nearly continuous chain of low hills that span $3 / 4$ of a circumference that is only interrupted in its NW quadrant, where the dome appears to be buried by (or developed in?) 

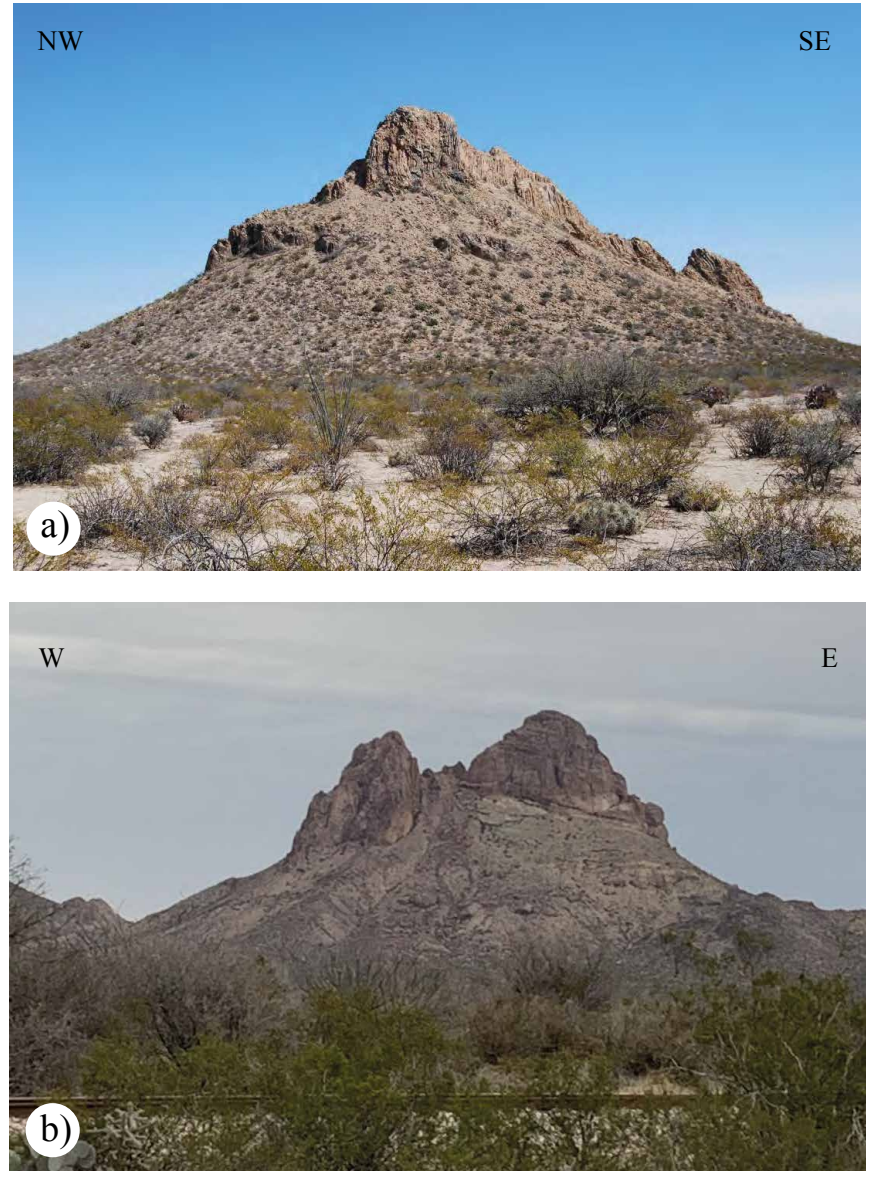

Figure 4. a) Cerro Dinamita is an elongated hill crowned by a vertical dike with conspicuous, nearly vertical, columnar joints. The hill seen from the SW has a jagged form, with two peaks that are surrounded by an apron formed by a talus deposit. b) Cerro Las Tetas de Juana, located a short distance north of the Escalón-Carrillo road; the steep hill on the left is a volcanic neck and the hill on the right is part of a tilted layered volcanic sequence. Both photos (a) and (b) depict deeply eroded volcanic vents, but Cerro Dinamita represents a deeper erosion level as all volcanic rocks have been removed.

volcanic rocks (Figure 7). We refer to this chain of hills as the uplifted dome fringe (DF: Figure 5b). As a whole, relief in the area occupied by the dome is moderate to low in most places, but there are several steep hills (cerros) within the dome and in its periphery. Inside the circular structure are three notable cerros: Piloncillo, Pintado, and Dinamita (Cpo, CP and CD: Figure 5b). Small sierras, formed by volcanic rocks, which gradually yield to colluvium and alluvial fan or aeolian deposits, surround these cerros. Cerro Dinamita is a small elliptical $(500 \times 200 \mathrm{~m}$ and $30 \mathrm{~m}$ high) landform in plan view, elongated in a N30W direction (Figures 4 and 5b).

A N60E-trending elevation profile across the dome (Figure 6a), through Cerro Pintado, the highest point within the dome ( $c a .1368 \mathrm{~m}$ a.s.l.), shows that as whole the structure is slightly higher to the west ( $1226 \mathrm{~m}$ a.s.l.) than to the east (1150 $\mathrm{m}$ a.s.l.), where the nearly flat alluvial plain gently slopes towards Laguna Palomas $\left(\sim 26^{\circ} 52^{\prime} \mathrm{N}, 103^{\circ} 54^{\prime} \mathrm{W}\right)$, the lowest point in an endorheic basin. A N40W-trending elevation profile through Cerro Pintado (1336 m a.s.l.) from the southwestern end of Sierra El Diablo to the northern part of Sierra Los Alamos shows that the relief inside the dome is very gentle to moderate except in those areas where volcanic rocks are exposed inside the structure. Both elevation profiles show that the dome fringe has low, very gentle
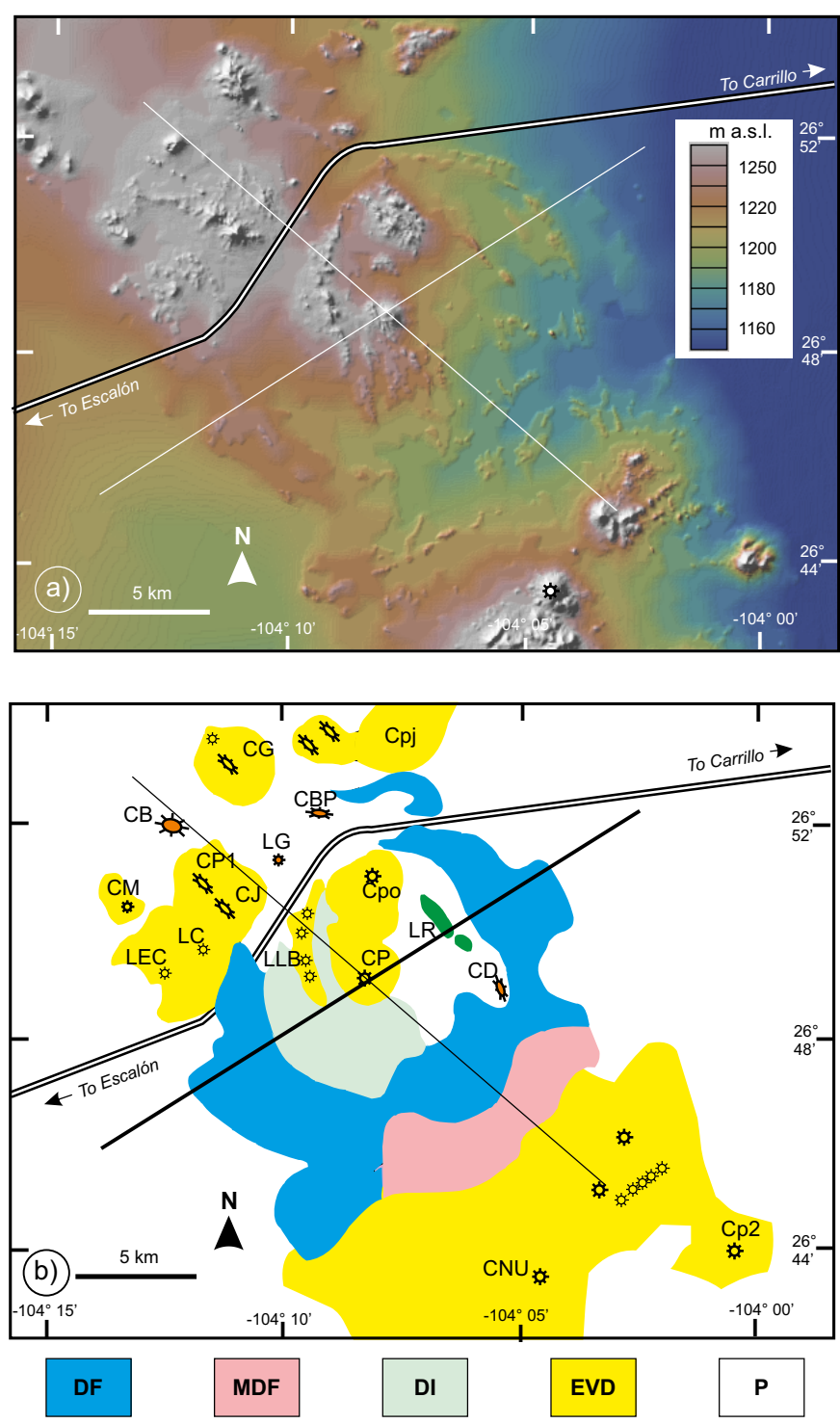

Figure 5. Physiography of the Mercurio structural dome region. a) Shaded relief map with hipsographic tints generated with GeoMapApp (http://www. geomapapp.org). The paved road from Escalón to Carrillo is shown in the upper portion of the image. The white lines correspond to the trace of the topographic profiles shown in Figure 6 and discussed in the text. b) Physiographic zonation of the area. Physiographic zones: $\mathrm{DF}=$ Dome fringe, $\mathrm{DI}=$ Dome interior, $\mathrm{EVD}=$ Eroded volcanic domain, $\mathrm{MDF}=$ Modified dome fringe, $\mathrm{P}=$ Plain . Acronyms: $\mathrm{CB}=$ Cerro Blanco, $\mathrm{CBP}=$ Cerro El Buen Pastor, $\mathrm{CD}=$ Cerro Dinamita, $C G=$ Cerro Gallineros, $\mathrm{CJ}=$ Cerro Las Tetas de Juana, $\mathrm{CM}=$ Cerro La Moneda, $\mathrm{CNU}=$ Cerro Narices de Urías, $\mathrm{CP}=$ Cerro Pintado, $\mathrm{Cpi}=$ Cerro Prieto, $\mathrm{Cp} 2=$ Cerro Prieto $2, \mathrm{Cpj}=$ Cerro El Pitonaje, $\mathrm{Cpo}=$ Cerro Piloncillo, LG = Loma Guadalupana, LEC = Loma El Corcho, LC = Loma La Cuarta, LLB $=$ Lomas Las Brujas, LR = Loma Redonda.

topography even in those places where the volcano-sedimentary succession is clearly folded in the dome fringe. Hills in the fringe barely rise up to 30 meters above their flat, gently inclined surroundings.

Between the western part of the dome's fringe and the small sierras around cerros Pintado and Piloncillo, there is a small arcuate chain of hills (e.g., Lomas Las Brujas, LLB, Figure 5b), made of intermediate to mafic volcanic rocks, which is roughly parallel to the dome's fringe. This disposition suggests that these rocks predate the dome formation or that 

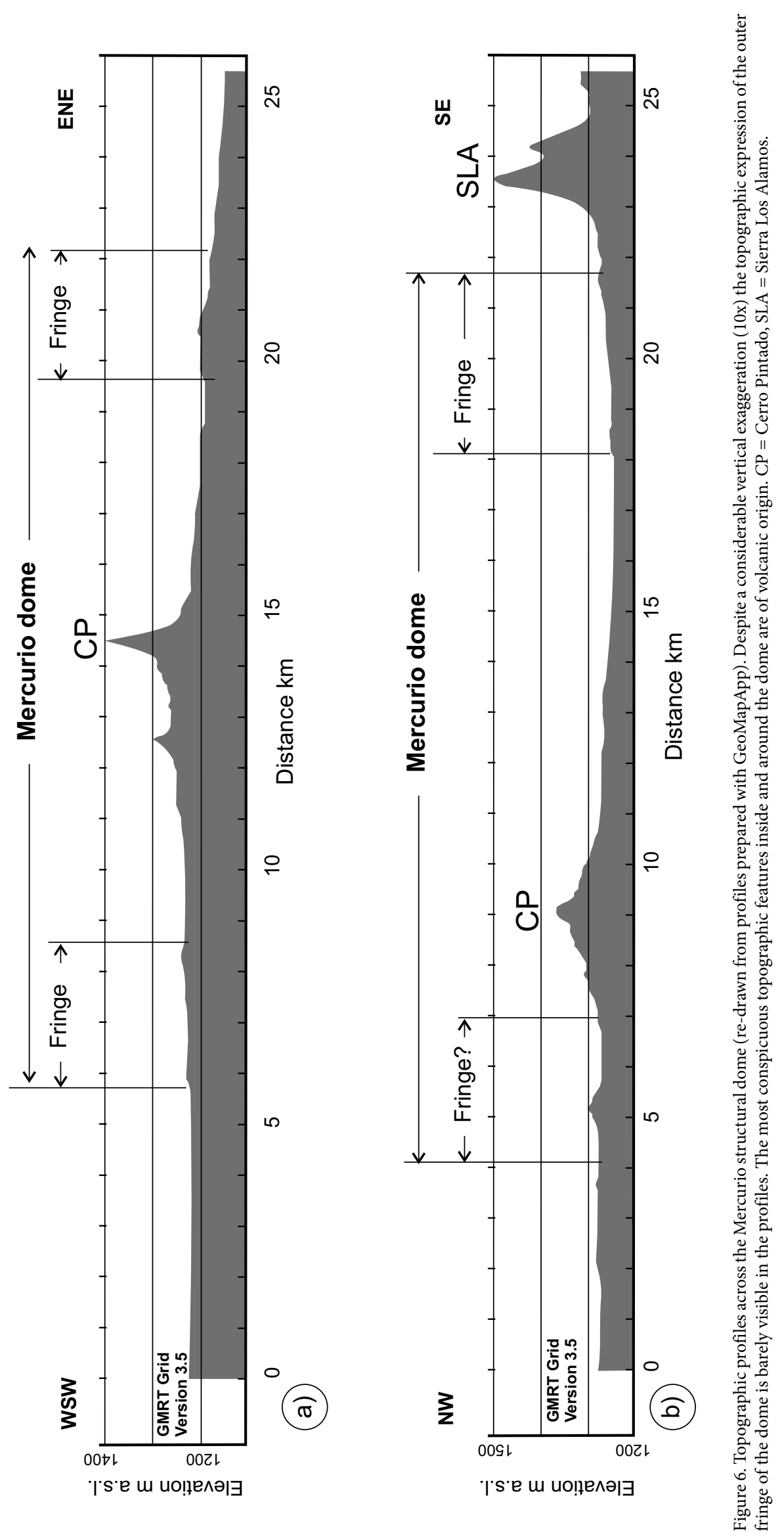

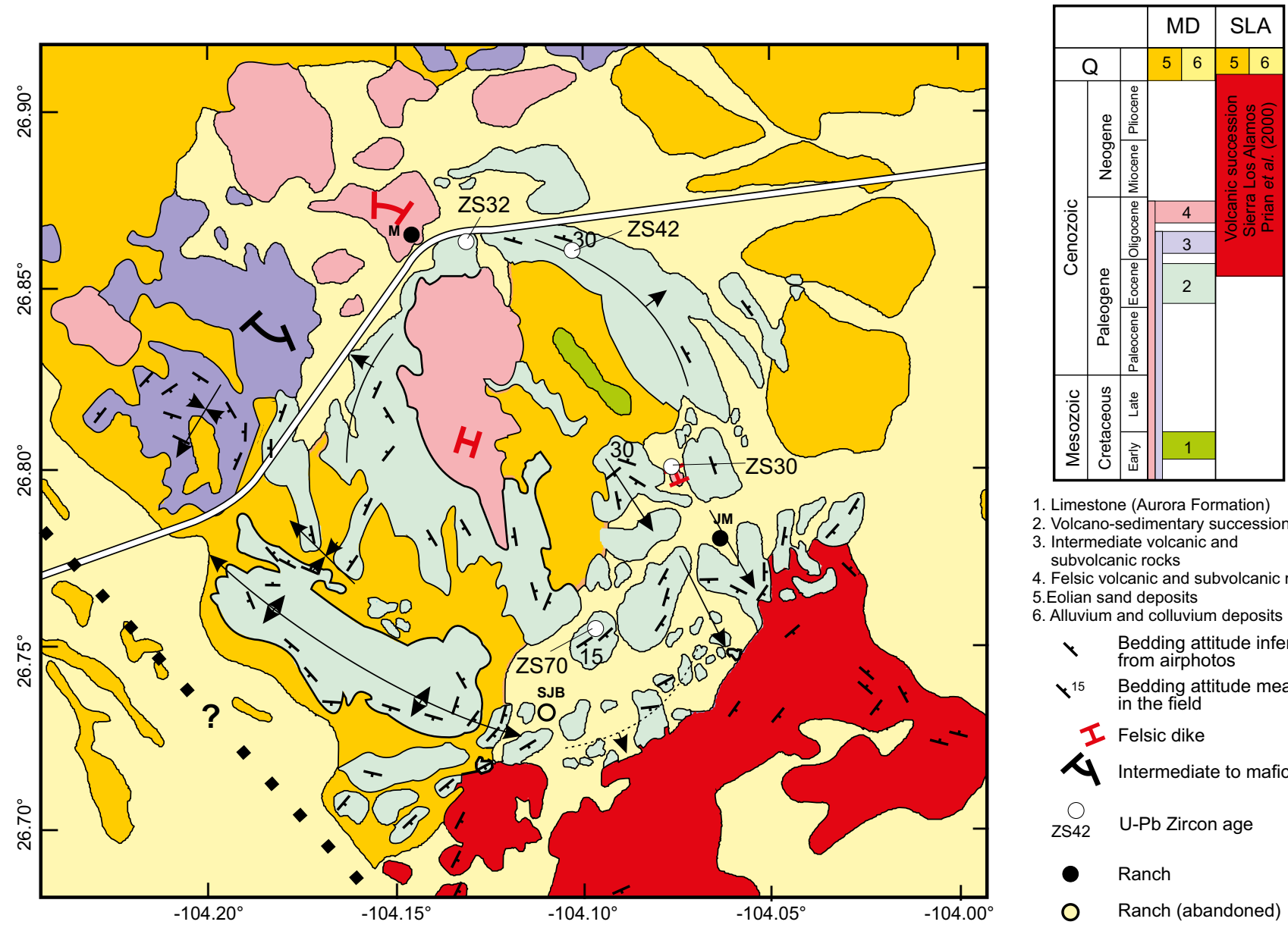

1. Limestone (Aurora Formation)

2. Volcano-sedimentary succession

3. Intermediate volcanic and

subvolcanic rocks

4. Felsic volcanic and subvolcanic rocks

5.Eolian sand deposits

6. Alluvium and colluvium deposits

× Bedding attitude inferred from airphotos

$\gamma^{15}$ Bedding attitude measured in the field

I. Felsic dike

4 Intermediate to mafic dike

ZS42 U-Pb Zircon age

- Ranch

O Ranch (abandoned)

$=\quad \begin{aligned} & \text { Paved road and } \\ & \text { railroad track }\end{aligned}$

Figure 7. Geologic sketch map of the Mercurio structural dome mostly based on the interpretation of vertical, 1:75,000-scale, stereo pair airphotos. Attitudes of the layers in the volcano-sedimentary unit were inferred from the asymmetry of cuestas (Figure 3) in aerial imagery. Resistant tabular rock bodies in the volcanic successions were also used to infer their attitude. The dotted line in the SW corner of the map shows the approximate location of a conspicuous lineament seen in the geophysical maps (Figures 13 and 14). It is represented by the symbol of a hidden fault. Sampling sites for U-Pb dating are shown. Ranchs: JM = Jesús María, $\mathrm{M}=$ Mercurio, $\mathrm{SJB}=$ San José del Bosque. Other acronyms: MD = Mercurio dome, SLA = Sierra Los Alamos.

they were emplaced along a curved fracture parallel to the dome fringe.

On the northwestern quadrant of the Mercurio structural dome (Figure 5b), outside the fringe, there is a series of steep hills, such as cerros Blanco (CB) and El Buen Pastor (CBP), which are isolated landforms, surrounded only by aprons of talus deposits. In the same area there are other notable topographic highs, such as cerros Prieto (CPi), La Moneda (CM), Gallineros (CG), and El Pitonaje (CPj) that are surrounded by lower, rounded hills made of felsic to intermediate volcanic rocks. Just south of cerros La Moneda and Prieto there is a set of low hills of volcanic origin that appear in the map as lomas El Corcho (LEC) and La Cuarta (LC); almost all of these individual hills are caped by remnants of a tabular and inclined lava flow.

The southern portion of the dome's fringe has a different morphology than other parts of this feature as it is formed by a series of isolated aligned cuestas that in places clearly define the outcrop pattern of plunging folds (Figure 7). Distal portions of alluvial fan deposits are in the process of burying the areas between these landforms. The proximal portions of these alluvial fans are located in the northwestern part of Sierra Los Alamos, which is the largest continuous highland near the dome.
Southwest of the dome is a flat, alluvial plain gently inclined towards the SE, which in places is masked by a thin cover of eolian deposits. The general trend of a major ephemeral stream (labeled " $c$ " in Figure 8) is subparallel to the orientation of a probable, NW-trending, buried normal(?) fault, which can be inferred from the geophysical data.

The drainage pattern (Figure 8 ) in and around the dome displays several notable features: 1 ) a weak annular array inside and around the fringe, 2) several conspicuous radial arrays around the highest hills inside and in the immediate vicinity of the dome. These arrays, together with the presence of volcanic neck-like morphologies are interpreted as evidence of deeply eroded volcanoes in the area.

\section{Stratigraphy}

\section{Aurora Formation}

Near the NE portion of the dome, just inside of the dome's fringe, there is an isolated hill surrounded by eolian deposits, where Cretaceous marine sediments are exposed (Figure 7). This elongated outcrop of pre-volcanic rocks is an upright, N45W-trending open anticline, where massive beds of limestone of the Aurora Formation are exposed (Prian 
et al., 2000). Rocks in the outcrop are mid to dark gray biomicrites or fossiliferous micrites with rare shells of pelecypods. Contorted internal laminations in the limestone layers were observed in few places.

\section{Volcano-sedimentary succession (Ahuichila Formation?)}

The outer fringe of the dome in the NE, SE and SW quadrants of the structure is constituted by this unit. This unit occurs in the areas labeled "dome interior" and "modified dome fringe" in Figure 5b. From marked color variations inside this unit, seen in satellite images (Figure 9) and field observations, it is known that there are marked local changes in the lithologies of this layered, poorly lithified unit. Calcareous sandstones with sparse pebble conglomerate horizons, andesitic conglomerate, moderately welded lithic-rich felsic ignimbrite, and partially welded felsic ignimbrite were recognized in isolated outcrops of this unit. Dark gray colors in satellite images correspond to andesitic conglomerate, whereas yellowish-brown to light gray colors represents calcareous sandstones and felsic ignimbrites. Almost everywhere this succession is covered by float made mainly by limestone and chert cobbles with occasional fragments of sandstone and volcanic rocks. This almost ubiquitous unconsolidated cover is interpreted as desert pavement.

Sandstones. A siliciclastic succession more than $20 \mathrm{~m}$ thick is poorly exposed both in the dome's fringe and in the central portion of the complex in the area SW of Cerro Dinamita. Lower and upper contacts are not exposed in the localities visited. These rocks range from moderately- to well-lithified and they are distinctly bedded. Their colors, both in the outcrop and in fresh surface vary from light greenish brown to white, and some of them are red. Thickness of the layers range from 2 to $12 \mathrm{~cm}$ and are commonly massive, but some beds are distinctly laminated, sometimes with reverse graded bedding or with low-angle cross stratification. Grain size in the sandstones usually is fine to medium, and in a few places exist thin layers or lenses of matrix-supported conglomerates made of pebbles to small cobbles of sub-angular to well-rounded limestone and rare volcanic clasts.

Sandstone ZS32 (Figure 7) is a tan-colored rock formed by subrounded grains and their framework constituents of are monocrystals and lithic grains. Quartz, K-feldspar, and plagioclase, partially replaced by calcite, occur as monocrystals. Clasts derived from volcanic rocks (microlitic and felsitic) and chert are present, whereas micritic limestones are the most common carbonate lithic grains. Grain size in a single sample sometimes ranges widely. This together with clast form (sub-angular to sub-rounded) and composition indicate the sandstones are immature calclithites sensu Folk (1974). Matrix appears to be absent or is masked by cement made of micritic carbonate. Some samples have a large intergranular porosity and are cemented by sparry calcite.

An isolated outcrop of red beds composed by red shale and reddish fine-grained sandstone is located in the south-central part of the dome. The basal contact of this sedimentary succession is not exposed

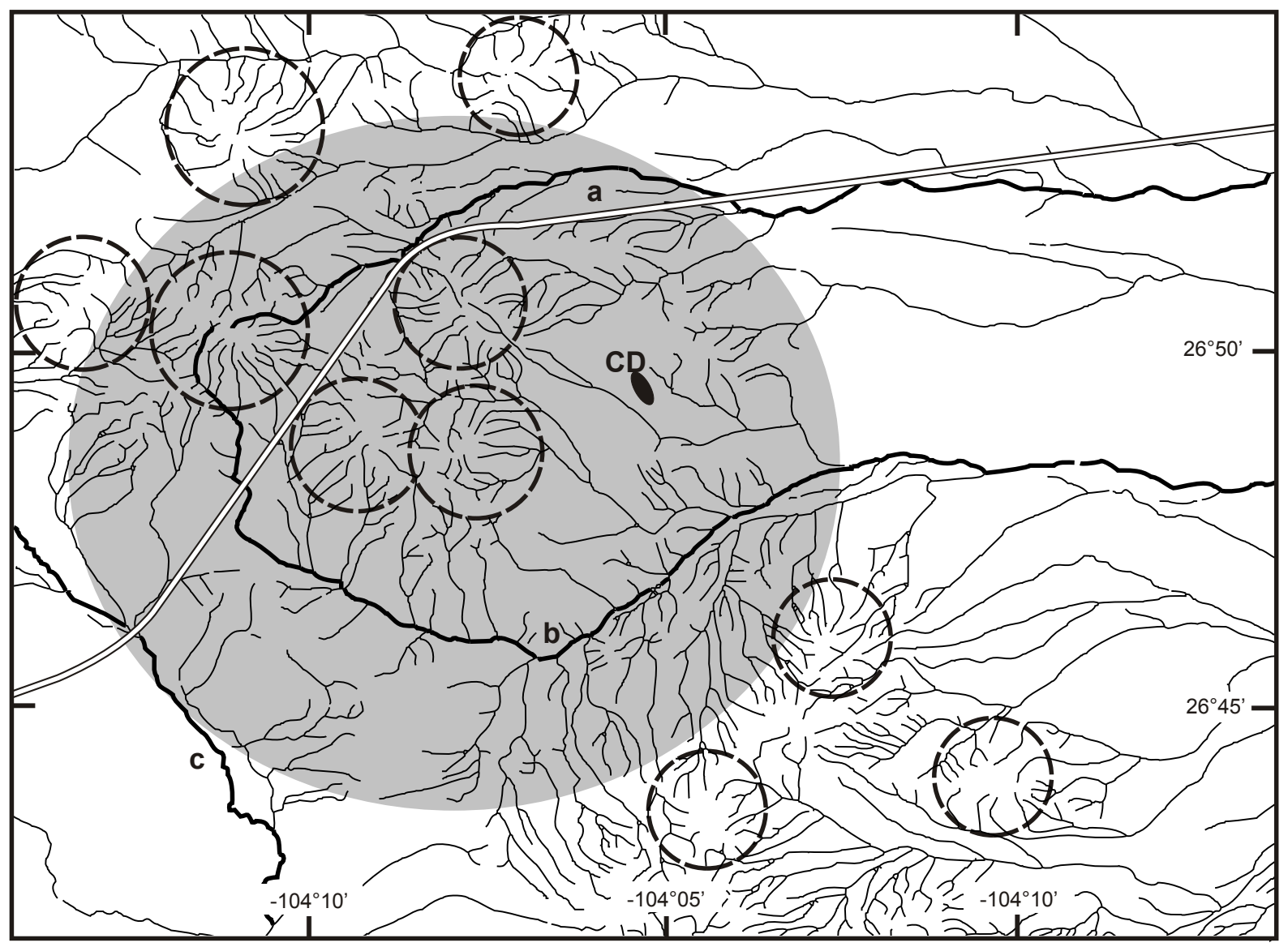

Figure 8. Hydrography of the Mercurio structural dome and its surroundings. The approximate location of the uplifted area of the dome is shown in gray. Note that two of the most important arroyos ( $\mathrm{a}$ and $\mathrm{b}$ ) in the area make a rough annular array within the gray area. Minor arroyos inside and north of the dome define radial arrays, such as those expected in partially eroded volcanic centers. Cerro Dinamita (CD), where an isolated subvolcanic dike is exposed (Figure 4a), lacks a clear radial pattern. West of the dome there is an extensive alluvial plane where the main stream (c) is parallel to the lineament seen in Figures 13 and 14 . Circular areas bounded with dotted lines are zones where streams display radial arrays. 


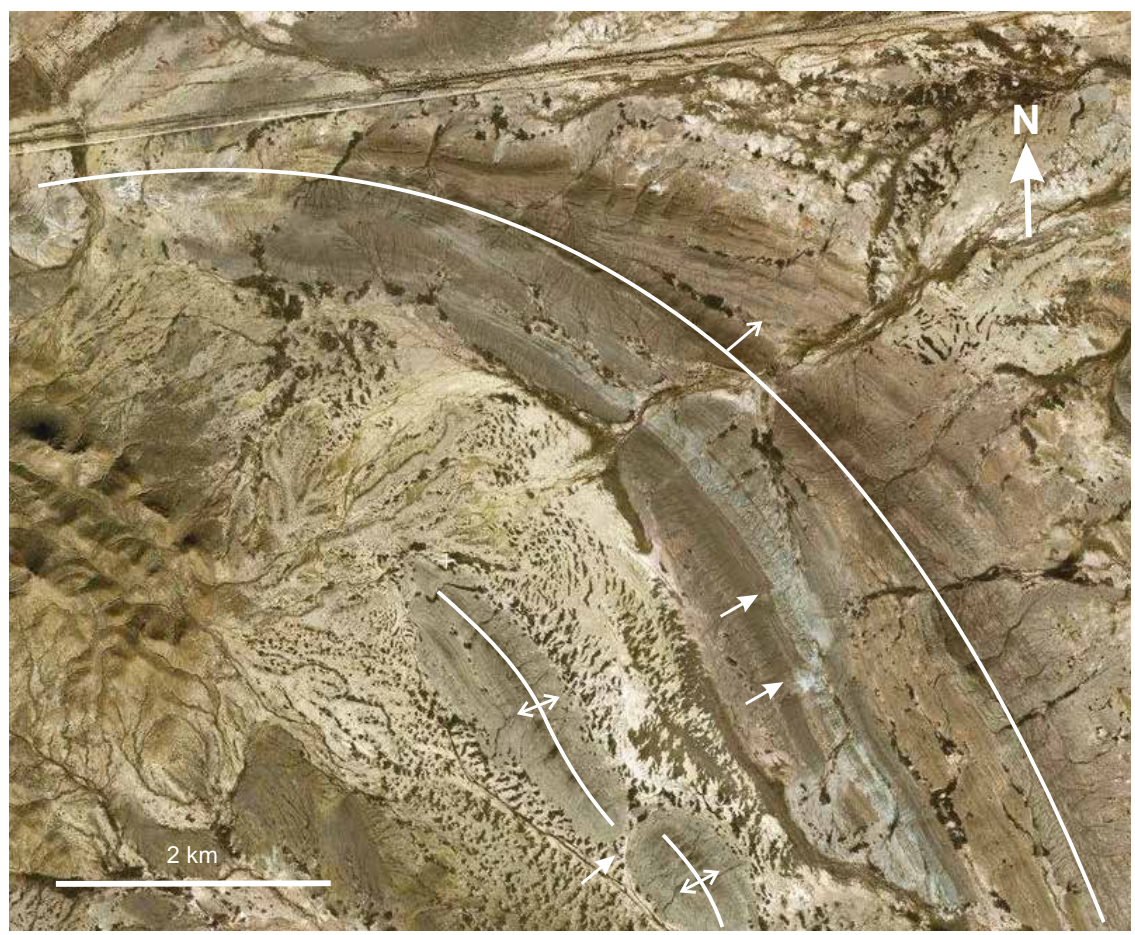

Figure 9. Satellite view of the NE portion of the dome's fringe (https://zoom.earth/\#0,0,3z,sat,pm,2018-05-23). Note the marked color changes in the volcanosedimentary succession; these variations reflect different lithologies. Also note the presence of small dextral strike-slip faults, which displace some beds (arrows). Some beds pinch-out along the strike.

because it is covered by alluvium, while the upper contact is eroded by uplift at all visited localities. These sandstones are thinly laminated and beds range from 13 to $15 \mathrm{~cm}$ in thickness. A sandstone sample of this succession was collected for geochronological analysis (ZS70, Figure 7). The sandstone sample is well-sorted, composed of sub-rounded to rounded grains of quartz, plagioclase, carbonate lithic grains, and volcanic lithic grains. Volcanic lithic grains and plagioclase are partially replaced by calcite.

Conglomerate exposed near Mercurio. Four kilometers east of the Mercurio ranch, a conglomeratic succession, more than $5 \mathrm{~m}$ thick is exposed in a small and shallow quarry located just south of the Escalón-Carrillo road (Figure 8). This succession is formed by massive to weakly stratified and poorly sorted conglomerate. The lower contact of the unit is not exposed in the quarry and upper contact is covered by lithic-rich moderately welded felsic ignimbrite. At the quarry exposure, the basal bed is a clast-supported conglomerate formed by rounded to well-rounded clasts of andesite (77\%), limestone (12\%), altered volcanic fragments (7\%), scant rhyolite $(2 \%)$, and very rare clasts of fine-grained sandstone. The upper beds consist of matrix-supported conglomerate interlayered with lenses of coarse sandstone. Clasts in upper portion conglomerate include andesite (48\%), limestone (39\%), rhyolite $(6 \%)$, intensely altered fragments of andesite with spheroidal weathering (5\%), rare chert, and finer grained rudite fragments. Clast sizes in this polymictic conglomerate range from pebbles to boulders. Boulders of rounded andesite may be up to $80 \mathrm{~cm}$ in diameter.

This particular conglomerate contrast with other rudites interlayered with sandstones of the volcano-sedimentary succession elsewhere, as clasts in those conglomerates are mostly derived from limestone, marls, and sandstones and their maximum diameter is up to $10 \mathrm{~cm}$. Thus, it is believed that the andesitic clasts observed in the Mercurio conglomerate are derived from a local source in the area.

Ignimbrites. Two different ignimbrite sheets were identified near the top of the deformed volcano-sedimentary succession. One lies atop the polymictic conglomerate (ZS-42 in Figure 7) with abundant andesite clasts and the other ignimbrite was observed in the southern part of the complex, between a sandstone and volcanic rocks of the northern part of Sierra Los Alamos. The sample collected atop the conglomerate is a lithic-rich, moderately welded ignimbrite, with abundant lithics, up to $20 \mathrm{~cm}$ in diameter of aphanitic andesite set in reddish-brown, devitrified, matrix with large fiammes (up to $5 \mathrm{~cm}$ ). The second ignimbrite is a salmon color, fine grained, nearly aphyric rock with up to $5 \%$ sanidine phenocrysts, less than $2 \mathrm{~mm}$ long.

Sample ZS42 came from the lithic-rich ignimbrite and seen under microscope has several remarkable textural features: the mafic fragments range in size from a few millimeters to several centimeters in diameter. The boundaries of mafic fragments in contact with the felsic matrix range from sharp to very diffuse (Figure 10a), a fact that suggests mixing and mingling of magmas of different compositions. One of the lava flows exposed north of the dome also displays a fabric that may be caused by mingling (Figure 10b). The borders of andesite fragments are composed by fine plagioclase microlites randomly oriented in a texture that has been interpreted by Troll et al. (2004) as produced by quenching of the more mafic magma dispersed in a cooler, more felsic magma. The felsic portion of the rock is nearly aphyric and cross polars reveals that is a cryptocristalline felsic aggregate, product of devitrification. The felsic matrix does not display a vitroclastic texture, but there are weak ghosts of finely banded devitrified glass that are interpreted as fiammes. There are marked changes in the content of opaque minerals within the rock. Opaque minerals are abundant in the best preserved portions of the more mafic inclusions, and more scarce in the transitional zones with the felsic host (Figure 10a). Banded, devitrified fiammes show a low content of opaque granules and occasionally contain sanidine phenocryst with honeycomb-like texture, interpreted as product of nearly complete fusion. 

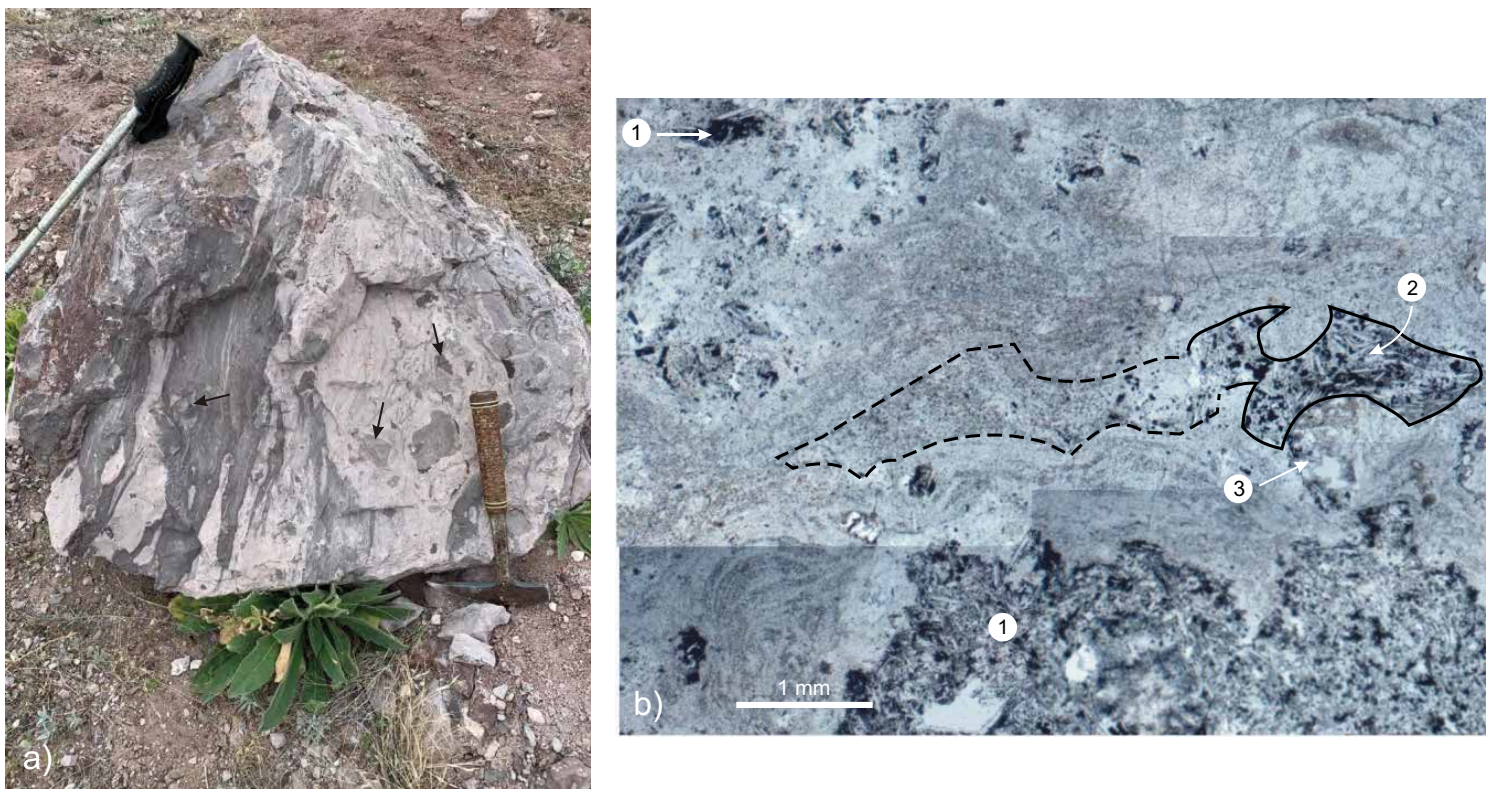

Figure 10. Some of the volcanic rocks associated to the dome display textures that suggest magma mixing and mingling. a) Lava block with a streaked appearance caused by the presence andesitic and rhyolitic domains. Note the presence of angular fragments of accidental andesite (indicated by arrows), both inside the light and dark colored streaks. Andesitic domains on the left side of the block have a "fiamme-like" appearance. b) Photomicrograph mosaic from sample ZS-42 where andesitic fragments $(1,2)$ appear to float in a felsic, foliated, nearly aphyric groundmass. The foliation is interpreted as product of compaction and welding in the ignimbrite. Note that some of the andesite fragments labeled (1) have sharp but irregular boundaries against the felsic magma. Morphology of the boundary between the largest domain of intermediate composition and felsic glass suggest interaction between liquids with different viscosities (e.g., Sklyarov and Fedorovskii, 2006). Some other intermediate domains (2) have fuzzy boundaries that indicate partial hybridization between both types of magma. A sanidine crystal (3) has a honeycomb-like texture. Plane polarized light. Field of view of the photomosaic is $5.2 \times 3.8 \mathrm{~mm}$.

The salmon-colored ignimbrite has a low content of sanidine phenocryst (up to $1 \mathrm{~mm}$ long) set in a vitroclastic matrix, composed by slightly flattened shards, which are devitrified and show the finegrained devitrification products arrayed as axiolites. Well developed spherulites replace the slightly flatened pumice fragments.

The matrix of both ignimbrites is partially replaced by calcite, which also appears to fill minuscule voids in the matrix.

\section{Cerro Dinamita intrusive}

This is a conspicuous topographic feature (Figure 4) inside the dome. It is located in the $\mathrm{E}$ part of the structure and it consists of a steep dike with nearly vertical columnar joints. The rock in the outcrop (ZS30 in Figure 7) is yellowish brown in color and displays flow foliation and microfolds. It is rhyodacite with $10-15 \%$ of plagioclase $>$ sandine > biotite phenocrysts, up to $3 \mathrm{~mm}$ long, set in an aphanitic, holocrystaline, felsophyric matrix. All phenocrysts tend to be euhedral to subhedral and are well preserved, without alteration or resorption. Quartz occurs mainly in the matrix as small irregular, optically continuous patches filling the voids between the sanidine and plagioclase microlites. Plagioclase and biotite form small glomeroporphyric aggregates, up to $5 \mathrm{~mm}$ long. Opaque minerals occur as small granules scattered in the matrix. Feldspar phenocrysts in the studied sample are partially replaced by calcite and sericite.

\section{Felsite domes and/or lava flows}

Inside the dome there is an extensive outcrop of felsic volcanic rocks, which include the cerros Pintado and Piloncillo and surrounding hills (Figures 5b and 7). Rocks in this unit usually are light colored (gray or brown) and commonly display flow foliation and the foliation attitude may be steep (up to $80^{\circ}$ ). In thin section, these felsites are holocrystalline, inequigranular-porphyritic, with 5 to $10 \%$ euhedral to subhedral phenocrysts of sanidine, set in an aphanitic matrix with the aspect of devitrified glass. Some rocks contain conspicuous, relatively coarse-grained spherulites alternating with bands of micro- to cryptocrystalline, mosaic-like felsic aggregates. Quartz is never present as phenocrysts but it appears to be present in the devitrified matrix, and it is abundant along thin veinlets or in irregular coarser-grained domains probably product of vapor-phase crystallization. Trace amounts of small microlites of a brown, slightly pleochroic, biotite(?) are the only ferromagnesian minerals present. Small granules of opaque minerals, together with the biotite microlites give a salt and pepper aspect to the microcrystalline portions of the matrix.

\section{Rocks exposed at Sierra Los Alamos}

From the southern part of the dome fringe to Ejido La Flor (Figure 1b) there is an arcuate chain of hills and mountains constituted by a layered volcanic succession, which in the regional geological maps (CETENAL, 1975; Prian et al., 2000) is shown as basalt, andesite, rhyolite and rhyolitic tuff. Inferred ages for this set of volcanic rocks in these maps ranges from Paleogene to Quaternary. The presence of volcanic necks and dikes (e.g., Cerro Las Narices de Urías), at the northern end of this sierra, suggests that this succession, in turn, may be underlain by another subvolcanic intrusion. This investigation was limited to the features exposed at the Mercurio structural dome, therefore no attempt was made to correlate the exposed rocks in Sierra de Los Alamos and those associated with the dome.

\section{Structure}

The first order structure in the studied area is that of a dome (Figure $7,8)$, where attitude of the layered rocks is quaquaversal with small to intermediate dips $\left(15-30^{\circ}\right)$. The northern portion of the dome is almost completely covered by volcanic rocks and the southern sector 
is partially masked by distal portions of alluvial fan deposits, whose apexes are located in the northern end of Sierra Los Alamos. The dome structure is simple in its NE quadrant (Figure 9), where it behaves as a monocline. The SE and SW portions are more complex, as a set of plunging folds are clearly exposed in those areas. All but one of the second order folds are NW-trending and roughly parallel to the nearby dome's outline. Fold axes in the SE quadrant of the dome plunge to the SSE, whereas the fold axes in the SW part of the dome plunge either to the SE or to the NW. In the western sector of the dome there is a NE-trending syncline axis, which plunges to the WSW. As a whole, the secondary fold axes are parallel to the outer fringe of the dome and dip away from the dome. Some of the fold axes are gently curved and concave towards the center of the dome.

\section{GEOCHRONOLOGY}

$\mathrm{U}-\mathrm{Pb}$ geochronology of zircon grains is a powerful tool for constraining maximum depositional ages of stratigraphic units (Dickinson and Gehrels, 2009; Spencer et al., 2016). This approach is especially useful for units lacking age-diagnostic fossils, such as those exposed in the Mercurio structural dome. The main premise of the method is that the age of deposit must be less than (or equal to) the age of the youngest zircon group found in the sample (Dickinson and Gehrels, 2009). The age estimation for a sedimentary succession can be better constrained if there are younger igneous rocks that can be analyzed together with the ages obtained from detrital zircons. This methodology is appropriate to constrain the age of the rocks that form the structure of the dome and unravel the stratigraphic relationships of its poorly exposed volcano-sedimentary succession. Additionally, it was tried to document the age of the youngest deformation event in the Mercurio area, assuming that the Cerro Dinamita dike is contemporaneous with the subvolcanic intrusion that caused the dome formation.

In order to obtain at least 50 zircon grains from igneous samples and 120 grains from detrital rocks, samples collected for geochronological analysis consisted of approximately $3-5 \mathrm{~kg}$ of rock. Detrital samples were primarily collected from medium-grained lithic sandstones that usually had a large proportion of limestone clasts, together with variable amounts of altered volcanic clasts and monocrysts interpreted as derived either from older sandstones of from alteration of paleovolcanic fragments. Individual zircons were analyzed by LA-ICPMS at the Laboratorio de Estudios Isotópicos, the Centro de Geociencias, UNAM, following the methods described by Solari et al. (2010, 2018). Cathodoluminiscence images were obtained prior to analysis to understand the internal structure of the analyzed zircon grains and determine optimal sites for laser ablation. For each tuff and igneous sample $\sim 30$ single crystals were analyzed. A minimum of $\sim 100-120$ grains were analyzed for detrital rocks. Analyses with discordance $>20 \%$ or reverse discordance $>5 \%$ are indicated by strikethrough text in the Supplementary Table S1 and were not considered further. Concordant grains were plotted as histograms and probability distribution functions using Isoplot software (Ludwig, 2008). Numerical ages are referred to the Geologic Time Scale of Cohen et al. (2013).

Four samples were selected to perform single crystal $\mathrm{U}-\mathrm{Pb}$ geochronology of zircons. Two of them are detrital samples (ZS32 and ZS70) collected at the northeastern and southern parts, respectively of the deformation fringe (Figure 7). Other sample from the volcanosedimentary succession is from the lithic-rich ignimbrite (SZ42: Figure 7).The fourth sample came from the Cerro Dinamita dike (ZS30: Figure 7). The salmon-colored ignimbrite seen in upper part of the volcano-sedimentary succession in the southern part of the dome did not contain zircons.

\section{Zircon $\mathrm{U}-\mathrm{Pb}$ ages of Mercurio sandstones and igneous rocks}

The maximum depositional age (MDA) from the ZS32 sample was determined by calculating the weighted average of the three youngest $\mathrm{U}-\mathrm{Pb}$ concordant zircon ages overlapping within $2 \sigma$ error. This sample yielded a weighted mean age of $49 \pm 2 \mathrm{Ma}$, which is consistent with the $48 \pm 1 \mathrm{Ma}$ age of the youngest analyzed zircon. The MDA of the ZS70 sample combines the two youngest concordant grain ages that overlap within $2 \sigma$ error because this sample did not provide three youngest individual $\mathrm{U}-\mathrm{Pb}$ ages commonly utilized in MDA determination. This sandstone yielded a weighted mean MDA of $50 \pm 11 \mathrm{Ma}$, which is consistent with the single youngest grain age $(49 \pm 1 \mathrm{Ma})$. These MDAs are interpreted as depositional ages, and represent the first absolute chronostratigraphic ages for Paleogene detrital rocks in the Mercurio area.

Due to the low number of valid analyzes (16) in the ZS32 sample, a data set that combines the $\mathrm{U}-\mathrm{Pb}$ ages of the ZS32 and ZS70 samples was used to infer the main age peaks in the sandstones of the Mercurio area. Detrital zircon ages in Mercurio sandstones range from 2018 to $48 \mathrm{Ma}$, and most ages (67\%, 80 out of 120 analyses) fall between $\sim 182$ and $48 \mathrm{Ma}$ (Figure 11). Detrital zircon ages are late Cretaceous (35\%), Proterozoic (22\%), Jurassic (13\%), Paleogene (12\%), early Cretaceous and Permo-Triassic (7\%), while early Paleozoic grains are the least abundant ( $4 \%$ ). The diagram has a main peak at $\sim 86 \mathrm{Ma}$, and minor peaks at $\sim 152, \sim 99$, and $\sim 51 \mathrm{Ma}$ (Figure 11, inset).

Most of the analyzed zircon grains in the igneous samples have a $\mathrm{Th} / \mathrm{U}$ ratio that exceeds 0.1 , which in combination with crystal textures indicate a magmatic origin (e.g., Rubatto, 2002; Corfu et al., 2003; Hoskin and Schaltegger, 2003). These zircon grains were used to better constraint the age of the succession in the Mercurio structural dome structure.

The lithic-rich ignimbrite (ZS42) collected near the top of the exposed volcano-sedimentary unit is younger than the sandstone samples as it contains six zircons with ages between 44 and $46 \mathrm{Ma}$ (Figure 12b). This sample yielded a U-Pb age of $46.4^{+0.8} /{ }_{-1.6}$ Ma with the TuffZirc approach. Of the analyzed grains, $67 \%$ are discordant (16 of 24 zircons). Thus, this imprecise age of $\sim 46 \mathrm{Ma}$ is attributed to magma mixing/mingling of felsic and intermediate magmas.

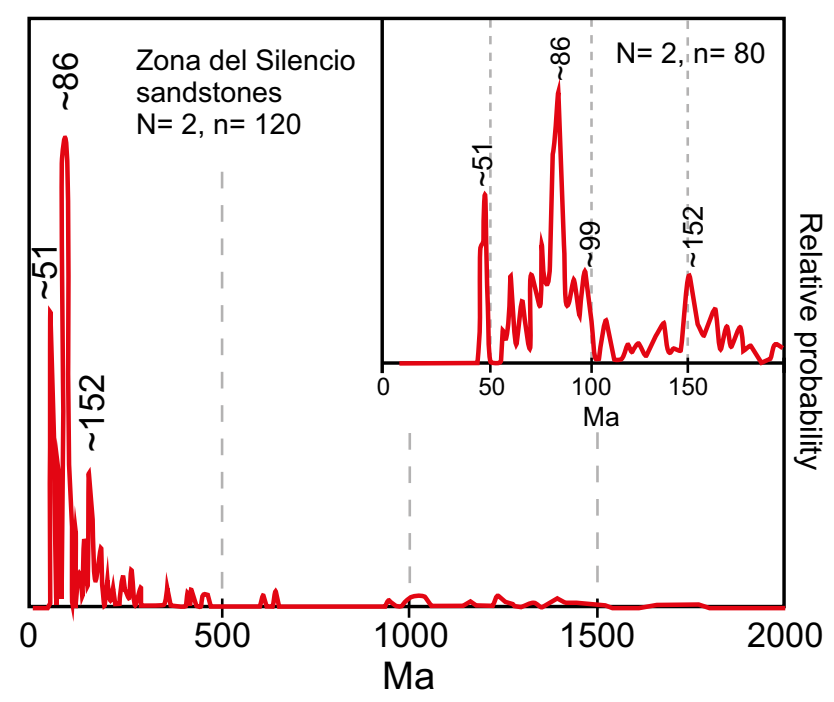

Figure 11. Probability density plot of combined detrital U-Pb zircon ages obtained for sandstone samples ZS32 and ZS70 collected at the deformation fringe of the Mercurio structural dome. $\mathrm{N}=$ number of samples, $\mathrm{n}=$ number of analyzed zircons. Inset shows grains younger than $200 \mathrm{Ma}$. 
Sample ZS30, collected at Cerro Dinamita, yielded a U-Pb age of $29.97^{+0.43} /_{-0.40}$ Ma with the TuffZirc approach, which is consistent with the youngest single grain age of $29 \pm 1 \mathrm{Ma}$ in the set (Figure 12c). Most of the $\mathrm{U}-\mathrm{Pb}$ ages have continuously-distributed single grain ages between $\sim 32-29 \mathrm{Ma}$ (91\%, 19 of 21 analyses). This sample contains two inherited zircons with ages of $\sim 42$ and $\sim 153 \mathrm{Ma}$ (Figure 12a).

\section{GEOPHYSICS}

Physiographic, hydrologic, and geologic evidence support the interpretation that the Mercurio structure is a dome developed mainly in a Paleogene volcano-sedimentary succession, which discordantly lies atop a thick sequence of Mesozoic carbonates of the Coahuila Platform. A reasonable hypothesis to explain the structure exposed on the surface is that the dome was formed by forceful emplacement of a shallow, subvolcanic intrusive, probably a laccolith or stock, and that the Cerro Dinamita dike is an offshoot of the main intrusive body. Furthermore, the exposed volcanic rocks inside and in the immediate surroundings of the Mercurio structure, suggests that more than one magma pulse, or a bimodal magma system was involved in the formation of this subvolcanic intrusive. Published aeromagnetic maps published (Hernández, et al., 1999; Gaona-Mota, 1999; CuevasCovarrubias et al., 1999) display a total magnetic field anomaly with intensity up to 30-40 nT, centered two kilometers N80W of the Jesús
María locality (Figure 7). This anomaly may be the expression of the subvolcanic intrusive complex.

There are several geophysical methods that can be used to support geological and structural interpretations, especially in areas where exposure is poor, depth of erosion is shallow, and/or available geologic data is limited. In general, geophysics adds a quantitative view of the third dimension to models mainly based on geologic maps, where the structure at depth is mostly inferred but not measured. However, the scale of the geophysical data set defines the limits and the validity of the deduced geophysical models.

Potential field methods (gravity and magnetic) were used to infer the probable geometry and depth of the intrusion below the surface. Satellite gravity data (IGB, WGM2012 model: Balmino et al., 2012) and the ultra-high resolution model of Earth gravity field (GGMplus) with $\sim 200 \mathrm{~m}$ spatial resolution, which is based on GRACE, GOCE, EGM2008 and SRTM topography data (Hirt et al., 2013), were used. Digital magnetic data were obtained from the Servicio Geológico Mexicano (SGM). The aeromagnetic information was generated by the SGM using a Scintrex cesium magnetometer with sensitivity of $0.001 \mathrm{nT}$, at a flying height of $300 \mathrm{~m}$ and parallel lines separated 1000 $\mathrm{m}$ between them, with control lines every 10,000 m. Several corrections and transformations are usually applied after data recording by the SGM. These procedures are commonly used to enhance aeromagnetic data and for its visualization in maps (Milligan and Gunn, 1997).

A regional Bouguer gravity anomaly map is shown in Figure 13a
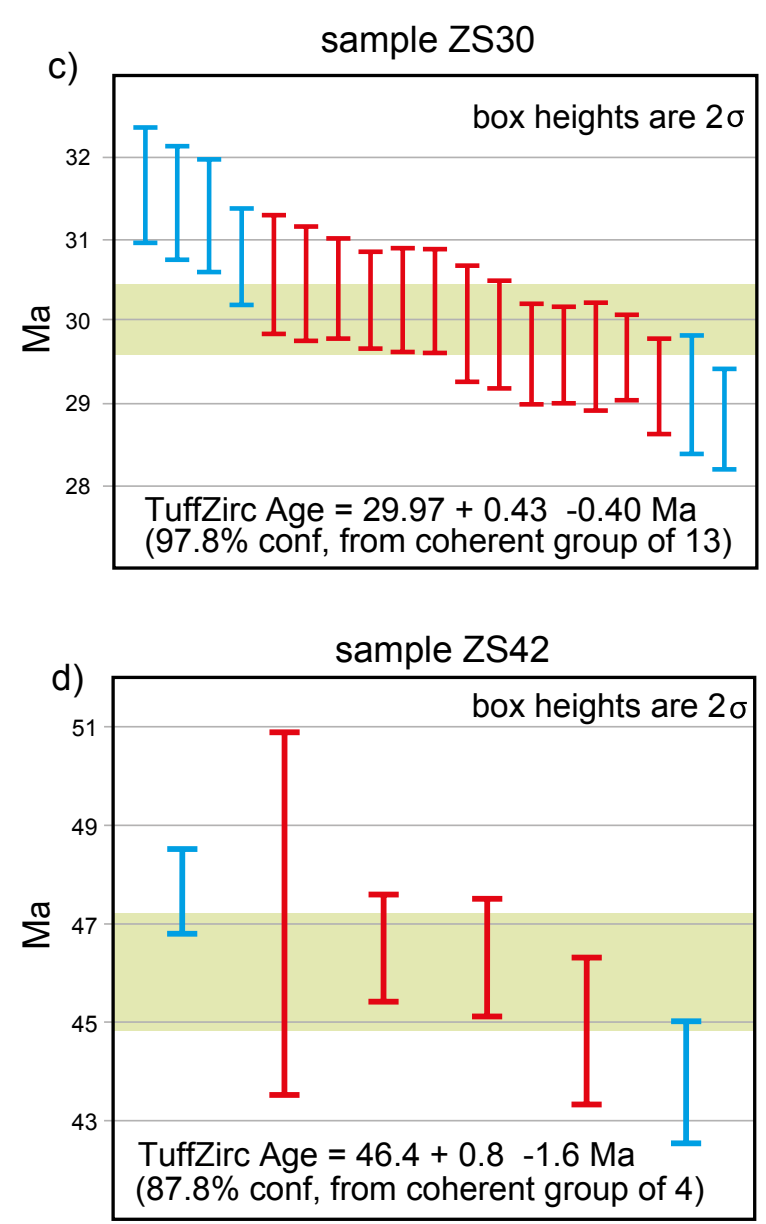

Figure 12. Probability density plot of sample ZS-30 (a) and sample ZS-42 (b); insets in both figures display the concordia plots. (c) and (d) Tuffzirc diagrams of the younger zircons in both samples. 
and the reduced to the pole magnetic anomaly map of the same region is depicted in Figure 13b. The aeromagnetic data was reduced to the magnetic pole using a magnetic intensity of $46541 \mathrm{nT}$, inclination $54^{\circ} 58^{\prime}$ and declination $08^{\circ} 47^{\prime}$. The total field anomaly was calculated on a regular grid with spacing of $0.25 \mathrm{~km}$. All geophysical maps in the paper display, as a reference, the dome trace at the surface with a white circle and the location of the Cerro Dinamita dike with a white asterisk. Geophysical maps (Figures 13-14) were constructed using minimum curvature as the interpolation method. This technique adjusts data points to a surface as smoothly as possible. The method is also an efficient interpolator for random data collected along arbitrary lines.

Both regional gravity and magnetic fields maps (Figures 13a and 13b) clearly show sets of NW-trending positive anomalies in the Mercurio structural dome region. These lineaments may be in part related to an important NW-trending normal fault shown by Prian et al. (2000), $20 \mathrm{~km} \mathrm{~N} 45 \mathrm{~W}$ of the study area. Another likely reason is the possible existence of an alignment of intrusive bodies in the area between the southwestern end of Sierra El Diablo and Sierra Los Alamos (Figure 1).

Figure 14 is a collection of processed gravity and magnetic data. Figure 14a shows the residual gravity field map obtained from the complete Bouguer anomaly data. It shows a local positive anomaly with maximum amplitude of about $10 \mathrm{mGal}$, however, it must be noted that the map resolution $(\sim 200 \mathrm{~m})$ is not enough to define the dome in any detail. In contrast, the residual magnetic anomaly map (Figure 14b) displays a well defined, isolated magnetic anomaly with an amplitude up to $180 \mathrm{nT}$ and also displays a clearly defined NW- trending magnetic minimum (dashed line in Figures 13 and 14), which has the same tendency hinted by the gravity anomaly in Figure 14a, and it also has an amplitude up to $180 \mathrm{nT}$.

Figures $14 \mathrm{c}$ and $14 \mathrm{~d}$ show the analytic signal and tilt derivate, respectively, which were obtained from the reduced to pole magnetic data. Both anomaly maps are prone to enhance lateral limit of source bodies as can be seen from these results. The amplitude of the analytic signal of the total magnetic field produces maxima over magnetic contacts regardless of the direction of magnetization. The analytical signal effectively "moves" the anomalies above the shallow magnetic sources, facilitates the $2 \mathrm{D}$ interpretation at depth, and its correlation with geologic features exposed on the surface. Analytical signal provides a simple method to estimate location of gravity and magnetic causative bodies (Baranov, 1957; Miller and Singh, 1994). As it can be seen, the analytical signal anomaly map of the studied area (Figure $14 \mathrm{c}$ ) is characterized by a strong positive anomaly above the central part of the hidden body, but also along what appears as a linear zone in the residual anomaly map (dotted line).

In order to evaluate the dimensions of the magnetized portion of the dome, a 2D joint forward model of gravity and magnetic residuals was carried out along the E-W profile shown in Figures 13 and 14. An algorithm proposed by Talwani and Heirtzler (1964) was used to produce a $2 \mathrm{D}$ model. This method allows the calculation of magnetic
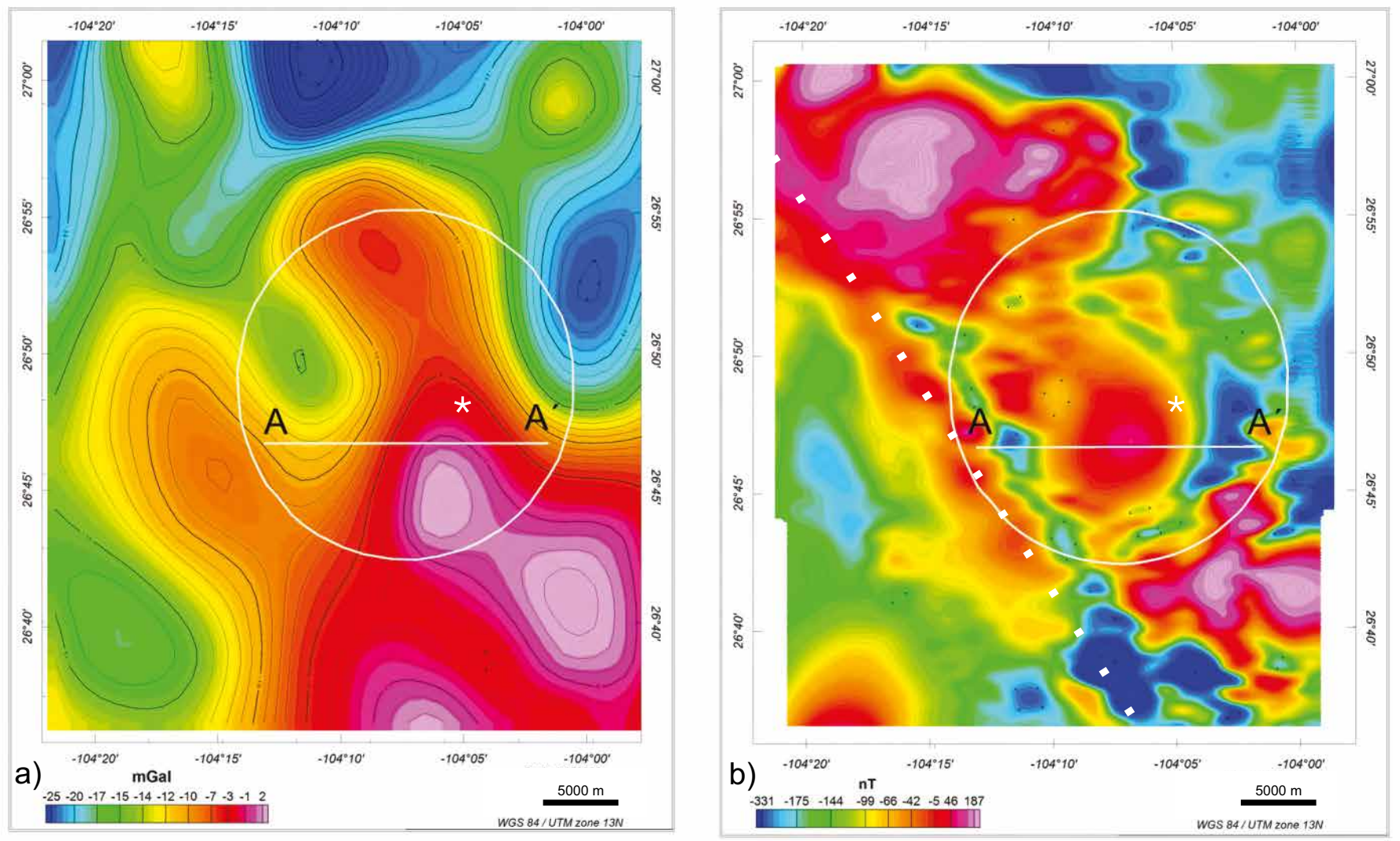

Figure 13. Regional Bouguer anomaly (a) and reduced to the pole aeromagnetic (b) maps of the region where is located the studied area. Both maps show that the dome (white circle) is in or near to high gradient zones. A clear NW orientation of the anomalies is seen in both maps (dotted line). The white asterisk marks the location of the Cerro Dinamita dike. Standard error in gravity is $0.1768 \mathrm{mGal}$ and in magnetic is $0.1817 \mathrm{nT}$. To generate the regional Bouguer anomaly map 1763 data points were used, and for the aeromagnetic map, 471,969 data points. The white line labeled A-A' corresponds to the section selected for the forward model shown in Figure 15. Supplementary File S2 includes variograms and histograms of the data used to elaborate maps in Figures 13 and 14, and data tables with additional information. 

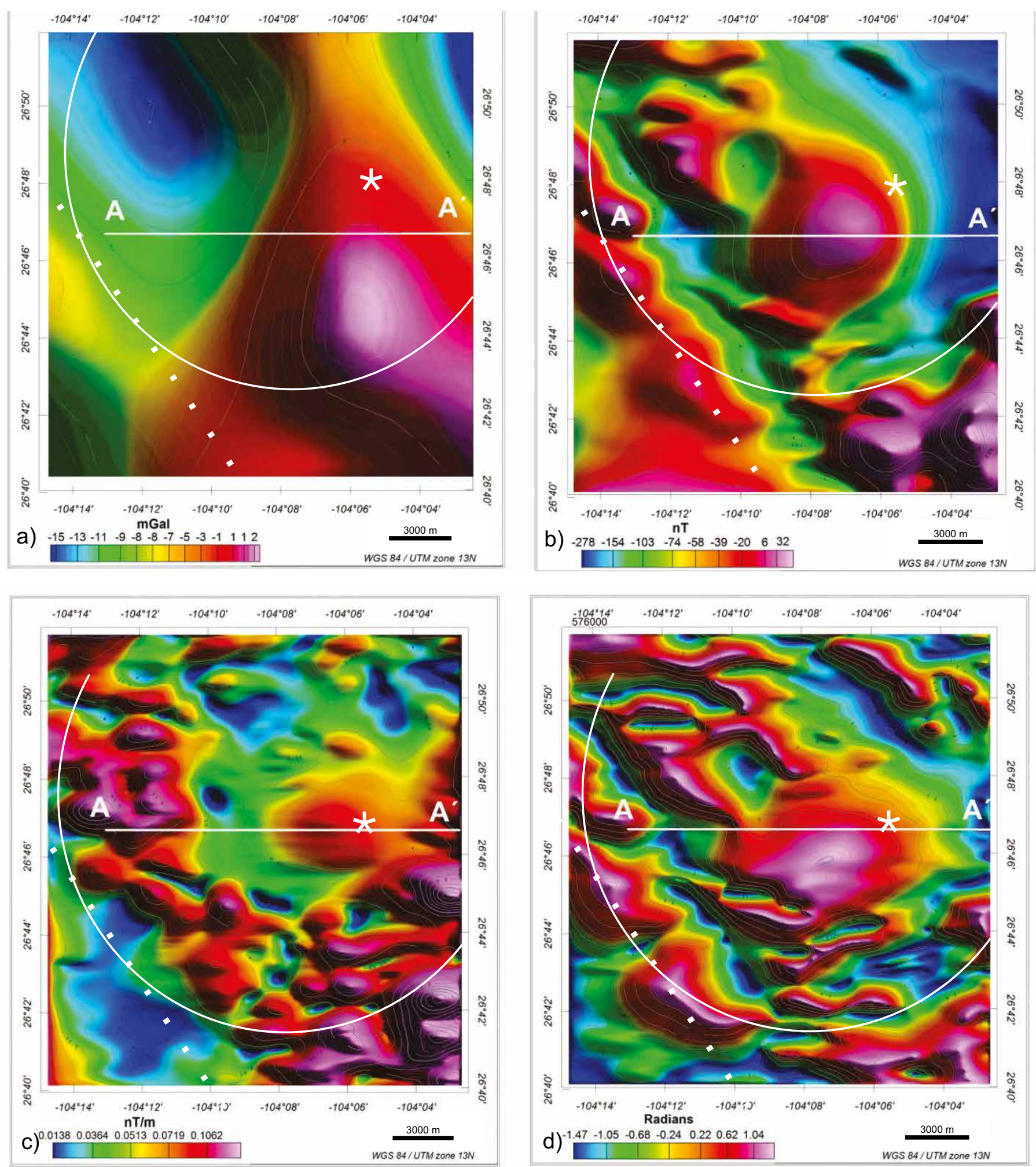

Figure 14. Processed gravity and magnetic data of the Mercurio structural dome and its immediate surroundings. (a) Residual Bouguer anomaly; standard error $0.1768 \mathrm{mGal}$. (b) Residual aeromagnetic anomaly reduced to the pole; standard error $0.2596 \mathrm{nT}$. (c) Analytical signal of the residual aeromagnetic anomaly reduced to the pole (std. err. $=0.000173 \mathrm{nT} / \mathrm{m}$ ). (d) Derived tilt of the residual magnetic anomaly reduced to the pole (std. err. $=0.0001701 \mathrm{Rad}$ ). 
a)

\begin{tabular}{|l|c|c|c|}
\hline Geological layer & $\begin{array}{c}\text { Colour } \\
\text { Density } \\
\mathrm{kg} / \mathrm{m} 3\end{array}$ & $\begin{array}{c}\text { Susceptibility } \\
\text { (SI) }\end{array}$ \\
\hline Eolian sand deposit & & 2000 & 0 \\
\hline Alluvium and colluvium & & 2200 & 0 \\
\hline Intermediate to mafic volcanic and subvolcanic rocks & & 2730 & 0.0048 \\
\hline Felsic volcanic and subvolcanic rocks & & 2670 & 0.0005 \\
\hline Volcano-sedimentary succession & & 2640 & -0.0003 \\
\hline Aurora Formation & & 2670 & -0.0006 \\
\hline
\end{tabular}

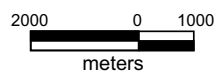

Measured

Calculated
A

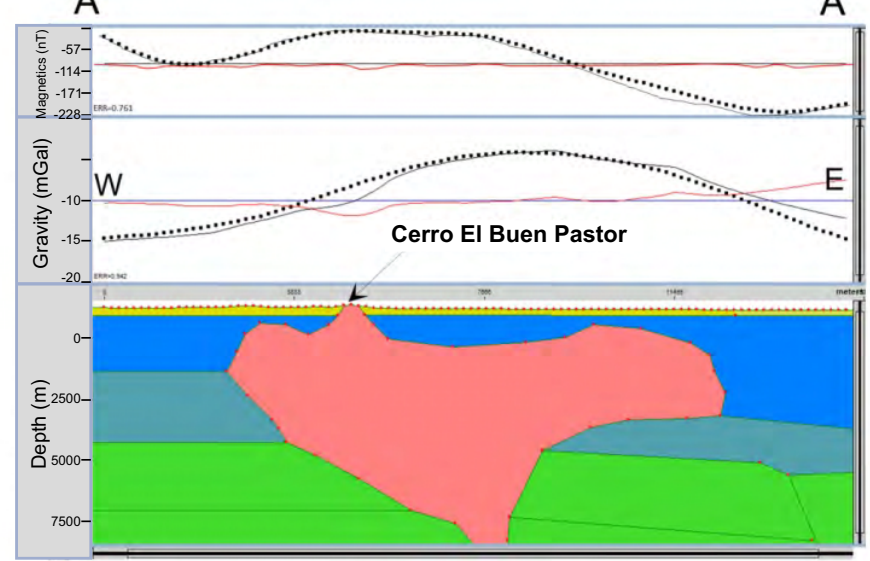

b)

Susceptibility

(SI)

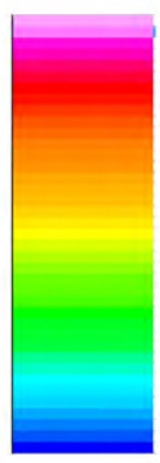

0.0048

0.0005

0.0002

0.0000

$-0.0002$

$-0.0004$

$-0.0006$

$-0.0068$

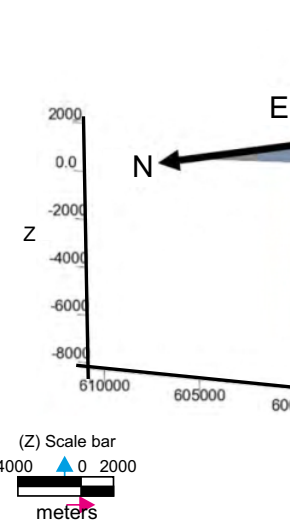

Cerro El Buen Pastor

Figure 15. (a) 2D joint forward model of gravity and magnetic residuals showing the best fit of observed and calculated anomalies (errors for gravity and magnetic modeling are $0.942 \mathrm{mGal}$ and $0.761 \mathrm{nT}$, respectively). Density and magnetic susceptibility values correspond to the lithologies observed on the surface. (b) 3D voxel-based based inversion (Ellis and Macleod, 2013) of the residual of the total magnetic field data of the Mercurio structural dome area calculated with the Oasis Montaj ${ }^{\oplus}$ software. The magnetic structure associated with the dome consists of a central positive core surrounded by a mosaic-like periphery. Oasis Montaj ${ }^{\infty}$ software also gives an estimate of the surface and volume of the body, which are $318 \mathrm{~km}^{2}$ and $533 \mathrm{~km}^{3}$, respectively.

anomalies produced by bidirectional bodies of arbitrary shapes, represented by irregular polygons in a cross section. Modeling began with simple geometries such as spheres, cylinders (approximately a stock), half spheres ( laccolith), and the depth of the bodies were changed trying to reproduce the observed anomaly. Figure 15a shows the final 2D geophysical model of the dome, based on the best fitting of gravity and magnetic data. The model consists of a magnetized body nearly $10 \mathrm{~km}$ long, mostly buried at shallow depths (at most 2 $\mathrm{km}$ ) that almost reaches the surface in the western part of the section. Apparently the body has an asymmetrical form in its downward projection. Influence of the Cerro Dinamita dike is not registered in the model as the E-W section line does not cut it.

Finally, a 3D inversion of the residual of the total magnetic field data of the dome area was also performed using the Oasis Montaj ${ }^{\circ}$ software, which uses the magnetic vector inversion method, a technique that incorporates induced and remnant magnetizations without prior knowledge of the magnitude or direction of the field (Ellis et al., 2013; Johnson and Aisengart, 2014). Figure 15b shows the results obtained, which clearly display a well-defined, magnetized body broadly under the area where Cerro Dinamita is located. The upper contact of the intrusive with the country rock lies at a depth of $\sim 1$ to $2 \mathrm{~km}$ below the surface. Furthermore, as observed from the residual of the magnetic anomaly map of the region (Figure 13b), the anomalous magnetic anomalies appear to follow a NW regional structural trend, that could be interpreted as a hidden fault or fracture zone that allowed ascent of magma batches to the surface during the Paleogene.

\section{SIGNIFICANCE OF THE MERCURIO STRUCTURAL DOME}

Paleogene domes are fairly common around shallow intrusive bodies in northern Mexico. They are reported as clusters or alignments, such as the Candela-Monclova intrusive belt (CMIB: Chávez-Cabello, 2005; Figure 2a) or the intrusions in the Concepción del Oro block (Ramírez-Peña et al., 2019) located at the transitional zone between the Transverse Ranges of the Sierra Madre Oriental and the Mesa Central. Their cross-cutting and age relations respect to Laramide or Sevier structures are variable, as some of the domes are simple quaquaversal structures that appear to have deformed sequences, which originally had horizontal layering, whereas other domes produce complex deformation aureoles with refolding of older structures such as thrust faults and folds. 

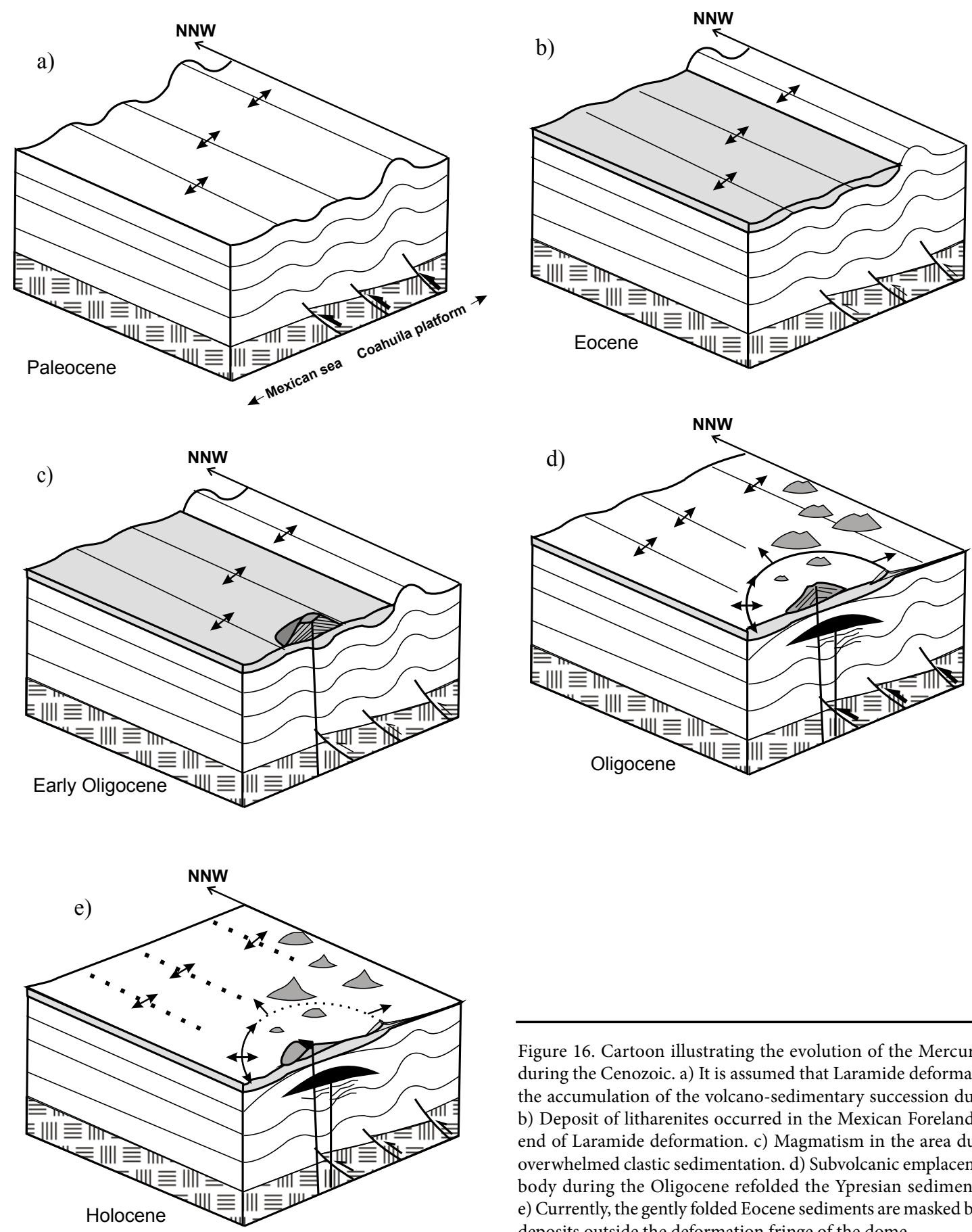

Figure 16. Cartoon illustrating the evolution of the Mercurio structural dome during the Cenozoic. a) It is assumed that Laramide deformation started prior to the accumulation of the volcano-sedimentary succession during the Paleocene. b) Deposit of litharenites occurred in the Mexican Foreland Basin, prior to the end of Laramide deformation. c) Magmatism in the area during the Oligocene overwhelmed clastic sedimentation. d) Subvolcanic emplacement of the intrusive body during the Oligocene refolded the Ypresian sediments and ignimbrites. e) Currently, the gently folded Eocene sediments are masked by alluvial and eolian deposits outside the deformation fringe of the dome.

Those domes that are more profoundly eroded than the Mercurio structural dome expose intrusive bodies near their centers, a metamorphosed aureole at their contact with the country rocks, and often show evidence of mineralization, which may be important as in the Concepción del Oro and Velardeña regions (Ramírez-Peña, 2014; 2017) or occur in areas without important mines present as in Sierra de Sarnoso (Kellum et al., 1936), a short distance NNW from Torreón (Figure 2a).

The topographic expression of the domes is highly variable. In some places as in Sierra de Sarnoso, the intrusive rock at the core is eroded inside a circular depression, and the resistant metamorphic aureole

forms an inward-facing escarpment, several hundred meters higher than the central depression where the intrusion is exposed. Other domes, such as Mercurio, which has a considerable larger diameter $(\sim 16 \mathrm{~km})$ than that at Sierra de Sarnoso $(\sim 12 \mathrm{~km})$, have a poor topographic expression and the structure is a barely visible deformation fringe without traces of contact metamorphism and scarce evidence of $\mathrm{Hg}$ mineralization (Prian et al., 2000).

The Mercurio structural dome is an example of a poorly exposed structure where the use of geophysical modeling (e.g., Hunt et al., 1995; Phillips, 2000) is required to infer its size, depth, volume, and other structural characteristic of the hidden portion of the subvolcanic body. 


\section{DISCUSSION}

\section{The evolution of the Mercurio structural dome}

The Paloegene volcano-sedimentary succession is poorly exposed in the deformed fringe and interior of the dome. The isolated outcrops visited indicate that it is constituted by an interlayered sequence of litharenites, scant conglomerates, and ignimbrites. Zircon maximum depositional age ( $\sim 51 \mathrm{Ma})$ obtained from the combined single grain ages of sandstone samples ZS32 and ZS70 (Figure 11) corresponds to the Ypresian, whereas the lithic ignimbrite, which lies atop the detrital rocks, yields an emplacement age of $\sim 46 \mathrm{Ma}$. It is assumed that the shallow intrusive exposed at Cerro Dinamita ( $29 \mathrm{Ma})$ represents an offshoot of the subvolcanic intrusion, which is still, for the most part, buried under the dome (Figure 15b). Based on the lithology of the Mesozoic sedimentary rocks exposed inside the dome, the regional geologic setting, and the fact that the Aurora limestone is exposed as an upright, open anticline, it is concluded that the intrusive was emplaced in rocks of the Coahuila Calcareous Platform and in the overlying detritic succession (Figure 16). The fact that the deformation fringe displays several NW-trending folds in the volcano-sedimentary succession is taken as evidence that this unit was gently folded prior to the intrusion emplacement, in the time lapse between the eruption of the lithic rich ignimbrite ( $46 \mathrm{Ma})$ and the formation of the subvolcanic intrusion at Cerro Dinamita ( 29 Ma).

Thus, late Laramide folding in the region occurred in the lapse 46-29 Ma. This age for the late folding is similar to that obtained by Chávez-Cabello in the Monclova Intrusive Belt ( $41 \mathrm{Ma}$ : ChávezCabello, 2005) for the last pulse of Laramide deformation in that area. It is believed that the plis $d u$ fond in the Ahuichila Fm, reported by Tardy (1980) for the Parras Basin, may be Eocene-early Oligocene (Ramírez-Peña and Chávez-Cabello, 2017) in age, rather than Miocene.

The depositional environment of the volcano-sedimentary succession in the Mercurio region is unknown as the unit is almost completely covered by younger sediments everywhere. It is clear that the sandstones have an unusual lithology as lithic clasts derived from limestone are abundant in them. The isotopic age of both the sandstones (ZS70 and ZS32) and the ignimbrite (ZS42) are within the range expected for the Ahuichila Formation and other red-bed deposits (e.g., Aranda-Gómez and McDowell, 1998; Escalona-Alcázar et al., 2016), which occupy the same stratigraphic niche elsewhere in northern and central Mexico. However, by far, the most common lithology seen in the scant exposures in the Mercurio region is lithic sandstone, and gravelly facies is very rare, although the presence of abundant limestone and chert float as desert pavement may mask its real abundance in the area. The occurrence toward the top of the volcano-sedimentary succession of a coarse-grained polymictic conglomerate, in which andesitic boulders are dominant, and the presence of the ignimbrites in the deformed sequence is consistent with an increase, towards the top of the successions, of the volcanic content in most red-bed occurrences in Mexico (e.g., Aranda-Gómez et al., 1998; EscalonaAlcázar et al., 2016). Furthermore, the diameter of the largest andesitic clasts (up to $80 \mathrm{~cm}$ ) may be consistent with a nearby, local source in Mercurio.

\section{Significance of zircon ages in sandstones of the Mercurio structural dome}

Overall, Late Jurassic and Late Cretaceous age peaks recorded in Mercurio sandstone samples have been previously reported in the Difunta Group in northeastern Mexico (Lawton et al., 2009; 2016). A significant difference between Mercurio samples and those of the Difunta sandstones is in terms of Precambrian grains: with the exception of some Grenville grains, Precambrian zircons are rare in
Mercurio. In addition to this, the characteristic Laurentian basement grain-age component (e.g., $\sim 1.7 \mathrm{Ga}, \sim 1.4 \mathrm{Ga}$, and $\sim 1.1 \mathrm{Ga}$ ) seen in the Difunta sandstones is absent in Mercurio suggesting that Laurentian sources did not supply sediments to the Mercurio area during early Eocene time.

All analyzed zircon grains can be attributed to sources within Mexico. The pre-Jurassic grains constitute a minor set that is difficult to attribute to a specific source and can be a recycled component derived from sedimentary rocks present in northwestern Mexico. The Cretaceous and the Jurassic grains constitute the best represented group ( $149-70 \mathrm{Ma})$. The age interval of this set matches ages present in the magmatic arc of the western margin of Mexico. Late Jurassic grains can be derived from volcanic rocks such as the tuffs of the Cucurpe Formation in northern Sonora (e.g., Mauel et al., 2011). These rocks contain Proterozoic grains similar to those observed in the sample ZS70. Late Cretaceous grains ( 99-91 Ma) are inferred to be derived from igneous rocks widely distributed in the Baja California peninsula, particularly the Peninsular batholith (Kimbrough et al., 2001) or the Los Cabos batholith (Duque- Trujillo et al., 2015). The grain set that defines the main age peak at $\sim 86 \mathrm{Ma}$ may be the result of the erosion of Coniacian-Santonian pelagic and volcaniclastic rocks of the Caracol and San Felipe formations, exposed in northeastern and central Mexico (Juárez-Arriaga et al., 2019). These rocks crop out $\sim 270 \mathrm{~km}$ southeast of Mercurio and they could have been exposed since the early Eocene, slightly before the uplift Difunta Group in the Parras and La Popa basins in the latest Eocene and early Oligocene time (Soegaard et al. 2003). It is likely that zircons in this age range were derived directly from these volcano-sedimentary units. Alternatively, the source of these grains could be the Sinaloa batholith ( 100-45 Ma, Henry et al, 2003) or the Los Cabos Batholith ( 98-45 Ma: Duque- Trujillo et al., 2015). Other potential sources are found in the center of Sonora, where small plutonic bodies and volcanic successions have been recognized, whose ages vary between 90 and $70 \mathrm{Ma}$ (e.g., McDowell et al., 2001; Ramos-Velázquez et al., 2008; González-León et al., 2009, 2017). Late Cretaceous-early Paleogene ( $<70-49 \mathrm{Ma}$ ) grains constitute a minor set in the Mercurio sandstones that could be derived from intermediate volcanic rocks such as Peñas Azules, which were emplaced $\sim 68 \mathrm{Ma}$ in central Chihuahua (e.g., McDowell and Mauger 1994; McDowell; et al., 2001). The set of grains that spans 74-62 Ma may come in part from volcanic rocks present in central Sonora (González-León et al., 2011) or from plutonic rocks of the Sinaloa batholith (Henry et al., 2003). Additional sources could be volcanic fields in central Durango, which include ages between 53 and $40 \mathrm{Ma}$ (e.g., Aguirre and McDowell, 1993, Valencia-Moreno et al., 2017 and references cited therein).

\section{CONCLUSIONS}

1. The Mercurio dome is a complex structure formed by forceful emplacement of a subvolcanic intrusion. Cerro Dinamita is probably an offshoot of the intrusive. Thus, age of formation of the structure can be determined with $\mathrm{U} / \mathrm{Pb}$ analysis of zircons separated from this outcrop of the felsic intrusion.

2 . The deformation fringe around the dome is complex. This complexity is attributed to the presence of folds in the volcano-sedimentary succession prior to the dome formation. Maximum ages obtained from detrital zircons separated from sandstones from the succession are $49 \mathrm{Ma}$, and a crystallization age for an ignimbrite close to the top of the succession is $\sim 46 \mathrm{Ma}$. Thus, the last Laramide shortening pulse in the region is younger than $\sim 46 \mathrm{Ma}$.

3. Detrital zircon ages in Mercurio sandstones range from $\sim 2018$ to $48 \mathrm{Ma}$. The probability density plot of detrital U-Pb zircon ages has 
a main peak at $\sim 86 \mathrm{Ma}$, and minor peaks at $\sim 152, \sim 99$, and $\sim 51 \mathrm{Ma}$. These peaks are similar to those found in detrital zircon populations in some sandstones of the Difunta Group, except that Mercurio's samples contain significantly less Precambrian grains.

4. It it believed that the volcano-sedimentary succession at Mercurio may be correlated with the Ahuichila formation from the Transverse Ranges of the Sierra Madre Oriental.

\section{ACKNOWLEDGMENTS}

UNAM-DGAPA-PAPIIT IN100416 provided financial support for this research to J. Aranda. Juan Tomás Vázquez prepared the thin sections of the studied rocks. Alexander Iriondo and Roberto Molina discussed with us about the geochronology and geophysics, respectively. Special thanks are due to Jorge Arzate who read and edited the Geophysics section and helped to interpret the data. Nuri López assisted in the field. Three anonymous reviewers and Claudia Indira made useful comments and suggestions. Natalia Pardo Villaveces managed the edition of this paper, and Teresa Orozco performed a detailed editorial review of the final copy of the manuscript. While we were doing the field work we stayed at the Laboratorio del Desierto in the Reserva de la Biósfera de Mapimí, which depends from the Instituto Nacional de Ecología (México). Private land owners and ejido's administrators in the reserve granted permission to circulate in their lands. Members of the Herrera de la Cerda family, who manages the INECOL's Laboratorio del Desierto, made our stay in the area very pleasant and Julián Ruíz assisted in the field. We gratefully thank all these people for their help.

\section{SUPPLEMENTARY MATERIAL}

Supporting supplementary files S1 and S2 can be found at the journal web site $<$ http://rmcg.unam.mx/>, with the html version of this paper.

\section{REFERENCES}

Aguirre-Díaz, G.d.J., McDowell, F.W., 1993, Nature and timing of faulting and synextensional magmatism in the southern Basin and Range, centraleastern Durango, Mexico: Geological Society of America Bulletin, 105, 1435-1444.

Aranda-Gómez, J.J., McDowell, F.W., 1998, Paleogene extension in the southern Basin and Range Province of Mexico: Syn-depositional tilting of Eocene red beds and Oligocene volcanic rocks in the Guanajuato mining district: International Geology Review, 40(2), 116-134.

Aranda-Gómez, J. J., Carranza-Castañeda, O., Wang, X., Tseng, Z.J., and Pacheco-Castro, A., 2018, Notes on the origin of extensive endorheic regions in central and northern Mexico, and some implications for paleozoogeography: Journal of South American Earth Sciences, 83, 55-67.

Aranda-Gómez, J.J., Housh, T.B., Luhr, J.F., Becker, T., Solorio-Munguía, J.G., Martínez, E., 2001, Timing of multiepisodic deformation based on the study of continental clastic deposits and volcanic rocks, east-central Chihuahua, México: GEOS, 21(3), 204.

Aranda-Gómez, J.J., Luhr, J.F., Housh, T.B., Connor, C.B., Becker, T., Henry, C.D., 2003, Synextensional, Plio-Pleistocene eruptive activity in the Camargo volcanic field, Chihuahua, México: Geological Society of America Bulletin, 115(3), 298-313.

Aranda-Gómez, J.J., Housh, T.B., Luhr, J.F. Henry, C.D., Becker, T., ChávezCabello, G., 2005, Reactivation of the San Marcos Fault during mid- to lateTertiary extension, Chihuahua, México: Geological Society of America, Special Paper, 393, 509-520.

Aranda-Gómez, J.J., Chávez-Cabelllo, G., González-Cervantes, N., Molina-
Garza, R.S., 2016, Pliegues replegados asociados al emplazamiento de lacolitos durante el Paleógeno en la vecindad de la Plataforma de Coahuila, México: GEOS 36(1), 59.

Aranda-Gómez, J.J., Oviedo-Padrón, E., Chávez-Cabello, G., CarreraHernández, J., 2016, Alternancia de valles y sierras paralelas en el norte y centro de México; la disyuntiva entre montañas de bloque o sierras coincidentes con anticlinales: Universidad Nacional Autónoma de México, Boletín del Instituto de Geología, 120, 3-29.

Araujo-Mendieta, J., Arenas-Partida, R., 1986, Estudio tectónico-sedimentario en el Mar Mexicano, Estados de Chihuahua y Durango: Boletín de la Sociedad Geológica Mexicana, 47(2), 43-87.

Balmino, G., Vales, N., Bonvalot, S., Briais, A., 2012, Spherical harmonic modelling to ultra-high degree of Bouguer and isostatic anomalies: Journal of Geodesy, 86(7), 499-520. DOI: 10.1007/s00190-011-0533-4

Baranov, V., 1957, A new method for interpretation of aeromagnetic maps: Pseudo-gravimetric anomalies: Geophysics, 22, 359-382, doi: 10.1190/1 .1438369

Barbosa-Luna, D., Martínez-Ramos, C.J., Santiago-Carrasco, B., IzaguirreRamos, M.A., Gracia-Valadez, M.J., 1998, Carta geológico-minera Tlahualilo de Zaragoza G13-6, Coahuila, Durango y Chihuahua, scale 1:250,000: Pachuca, Servicio Geológico Mexicano, 1 map.

Cameron, K.L., Cameron, M., Bagby, W.C., Moll, E.J., Drake, R.E., 1980, Petrologic characteristics of mid-Tertiary volcanic suites, Chihuahua, Mexico: Geology, 8, 87-91.

Campa, M.F., Coney, P.J., 1983, Tectono-stratigraphic terranes and mineral resource distribution in Mexico: Canadian Journal of Earth Sciences, 20, 1040-1051.

CETENAL (Centro de Estudios del Territorio Nacional) 1975, Carta geológica Ceballos G13B63, Durango y Chihuahua, scale 1:50,000: México, D.F., Secretaría de la Presidencia, 1 map.

Chávez-Cabello, G., 2005, Deformación y magmatismo cenozoicos en el sur de la Cuenca de Sabinas, Coahuila, México: Universidad Nacional Autónoma de México, Querétaro, México, PhD. Thesis, 266 pp.

Cohen, K.M., Finney, S.C., Gibbard, P.L., Fan, J.X., 2013, The ICS International Chronostratigraphic Chart: Episodes, 36, 199-204.

Corfu, F., Hanchar, J.M., Hoskin, P.W.O., Kinny, P., 2003, Atlas of Zircon Textures, in Hanchar, J.M., Hoskin, W.O. (eds.), Zircon: Reviews in Mineralogy and Geochemistry, 53, 469-500.

Cuevas-Covarrubias, A., Bori S.E., Hernández P.I., 1999, Carta magnética de campo total, Mercurio, G13-B53, Estado de Chihuahua, scale 1:50,000: Secretaría de Economía, Servicio Geológico Mexicano, 1 map.

Dickinson, W.R., Gehrels, G.E., 2009, Use of U-Pb ages of detrital zircons to infer maximum depositional ages of strata: A test against a Colorado Plateau Mesozoic database: Earth and Planetary Science Letters, 288, 115-125.

Dickinson, W.R., Lawton, T.F., 2001, Carboniferous to Cretaceous assembly and fragmentation of Mexico: Geological Society of American Bulletin, 113(9), 1142-1160.

Duque-Trujillo, J., Ferrari, L., Orozco-Esquivel, T., López-Martínez, M., Lonsdale, P., Bryan, S.E., Kluesner, J., Piñero-Lajas, D., Solari, L., 2015, Timing of rifting in the southern Gulf of California and its conjugate margins: Insights from the plutonic record: Geological Society of America Bulletin, 127, 702-736. doi:10.1130/B31008.1

Edwards, J.D., 1955, Studies of some early Tertiary red conglomerates of central Mexico: U.S. Geological Survey, Professional Paper 264-H: 153-183.

Eguiluz de Antuñano, S., Aranda-García, M., Marret, R., 2000, Tectónica de la Sierra Madre Oriental, México: Boletín de la Sociedad Geológica Mexicana LVIII, 1-26.

Ellis, R.G., MacLeod, I.N., 2013, Constrained voxel inversion using the cartesian cut cell method, in ASEG-PESA 2013: 23rd International Geophysical Conference and Exhibition, Melbourne, Australia: ASEG Extended Abstracts 2013, 1, 1-4.

Escalona-Alcázar, F.d.J., Solari, L., García-Barragán, J.C., Carrillo-Castillo, C., Bluhm-Gutiérrez, J., García-Sandoval, P., Nieto-Samaniego, A.F., Núñez-Peralta, E.P., 2016, The Paleocene-early Oligocene Zacatecas conglomerate, Mexico: sedimentology, detrital zircon $\mathrm{U}-\mathrm{Pb}$ ages, and sandstone provenance: International Geology Review, 58(7), 826-848.

Flotte, N., Martínez-Reyes, J., Rangin, C., Le Pichon, X., Husson, L., Tardy, M., 2008, The Rio Bravo fault, a major late Oligocene left-lateral zone: Bulletin de la Societe Geologique de France, 179(2), 147-160. 
Folk, R.L., 1974, Petrology of Sedimentary Rocks: Austin, TX, Hemphill Publishing Company, 183 pp.

Gaona-Mota, M., 1999, Carta magnética de campo total, escala 1:250000, Hidalgo del Parral G13-5, Estado de Chihuahua: Pachuca, Servicio Geológico Mexicano, 1 map.

González-León, C.M., Valencia, V.A., Lawton, T.F., Amato, J.M., Gehrels, G.E., Leggett, W.J., Montijo-Contreras, O., Fernández, M.A., 2009, The lower Mesozoic record of detrital zircon U-Pb geochronology of Sonora, México, and its paleogeographic implications: Revista Mexicana de Ciencias Geológicas, 26(2), 301-314.

González-León, C.M., Solari, L., Solé, J., Ducea, M.N., Lawton, T.F., Bernal, J.P., González Becuar, E., Gray, F., López Martínez, M., Lozano Santacruz, R, 2011, Stratigraphy, geochronology and geochemistry of the Laramide magmatic arc in north-central Sonora, Mexico: Geosphere, 7(6), 1392-1418.

González-León, C.M., Solari, L.A., Madhavaraju, J., 2017, Stratigraphy, geochronology and regional tectonic setting of the Late Cretaceous (ca. 82-70 Ma) Cabullona basin, Sonora, Mexico, Journal of South American Earth Sciences, 80, 494-511 doi: 10.1016/j.jsames.2017.09.037

Hernández, C.A., Vélez-López, J., Hernández-Pérez, I., 1999, Carta magnética "Hidalgo del Parral" G13-5, Estados de Chihuahua y Durango, scale 1:250000, Texto guía: Consejo de Recursos Mineales, Pachuca, 25 pp.

Haenggi, W.T., 2002, Tectonic history of the Chihuahua trough, Mexico and adjacent USA, Part II: Mesozoic and Cenozoic: Boletín de la Sociedad Geológica Mexicana, LV(1), 38-94.

Henry, C.D., Aranda-Gómez, J.J., 1992, The real southern Basin and Range: mid-to late Cenozoic extension in Mexico: Geology, 20(8), 701-704.

Henry, C.D., McDowell, F.W., Silver, L.T., 2003, Geology and geochronology of granitic batholithic complex, Sinaloa, México: Implications for Cordilleran magmatism and tectonics, in Johnson, S.E., Paterson, S.R., Fletcher, J.M., Girty, G.H., Kimbrough, D.L., Martín-Barajas, A., (eds.), Tectonic evolution of northwestern México and the southwestern USA: Geological Society of America, Special Paper 374, p. 37.

Hirt, C., Claessens, S., Fecher, T., Kuhn, M., Pail, R., Moritz R., 2013, New ultrahigh-resolution picture of Earth's gravity field: Geophysical Research Letters, 40, 4279-4283. doi:10.1002/grl.50838

Hoskin, P.W.O., Schaltegger, U., 2003, The composition of zircon and igneous and metamorphic petrogenesis, in Hanchar, J.M., Hoskin, W.O. (eds.), Zircon: Reviews in Mineralogy and Geochemistry, 53, 27-62.

INEGI (Instituto Nacional de Estadística Geografía e Informática) 2008, Mercurio G13B53, Chihuahua y Durango, Carta topográfica, scale 1:50000: México, D.F., 1 map.

Johnson, A., Aisengart, T., 2014, Interpretation of magnetic data at low magnetic latitudes using magnetization vector inversion: Journal of Geophysics, 35(3), 91-96.

Jones, N.W., McKee, J.W., 1987, Pre-Cretaceous volcanic rocks at Sierra Diablo, Chihuahua: Universidad Autónoma de Chihuahua, Gaceta Geológica, $1(1), 82-96$.

Juárez-Arriaga, E., Lawton, T.F., Ocampo-Díaz, Y.Z.E., Stockli, D.F., Solari, L., 2019, Sediment provenance, sediment-dispersal systems, and major arcmagmatic events recorded in the Mexican foreland basin, North-Central and Northeastern Mexico: International Geology Review, doi.org/10.108 0/00206814.2019.1581848

Kellum, L.B., Imlay, R.W., Kane, W.G., 1936, Evolution of the Coahuila Peninsula, Mexico. Part I. Relation of structure, stratigraphy, and igneous activity to an early continental margin: Bulletin of the Geological Society of America, 47, 969-1008.

Keppie, D., 2004, Terranes of Mexico Revisited: A 1.3 Billion Year Odyssey: Internacional Geology Review, 46, 765-794.

Lawton, T.F., Bradford, I.A., Vega, F.J., Gehrels, G.E., Amato, J.M., 2009, Provenance of Upper Cretaceous-Paleogene sandstones in the foreland basin system of the Sierra Madre Oriental, northeastern Mexico, and its beraring on fluvial dispersal systems of the Mexicana Laramide Province: Geological Society of America Bulletin 121, 820-836.

Lawton, T.F., Juárez-Arriaga, E., Ocampo-Díaz, Y.Z.E., Beltrán-Treviño, A., Martens, U., Stockli, D., 2016, Evolution of late Cretaceous-Paleogene foreland sediment-dispersal systems of Northern and Central Mexico, in 35th Annual GCSSEPM: Houston, Texas, Fundation Perkins-Rosen Research Conference, Programs and Abstracts, 216-233.

Ludwig, K.R., 2008, ISOPLOT ver. 4.15: Berkeley Geochronology Center (BGC), http://www.bgc.org/isoplot_etc/isoplot.html (February 2017).

Martínez-Reyes, J., 1989, Interpretación estructural del frente de la Napa de Parras en el área de Viesca, Estado de Coahuila: Universidad Nacional Autónoma de México, Instituto de Geología, Revista 8(2), 123-133.

Mauel, D.J., Lawton, T.F., González-León, C., Iriondo, A., Amato, J.M., 2011, Stratigraphy and age of Upper Jurassic strata in north-central Sonora: Mexico: Southwestern Laurentian record of crustal extension and tectonic transition: Geosphere, 7, 390-414.

McDowell, F.W., 2010, Geologic map of the Manuel Benavides area, Chihuahua, Mexico: GSA Map and Chart Series MCH099, 20.

McDowell, F.W., Mauger, R.L., 1994, K-Ar and U-Pb zircon chronology of Late Cretaceous and Tertiary magmatism in central Chihuahua State, Mexico: Geological Society of America Bulletin, 106, 118-132.

McDowell, F.W., Roldán-Quintana, J., Connelly, J.N., 2001, Duration of late Cretaceous-early Tertiary magmatism in east-central Sonora: Mexico: Geological Society of America Bulletin, 113, 521-531.

McKee, J.W., Jones, N.W., Long, L.E., 1990, Stratigraphy and provenance of strata along the San Marcos fault, central Coahuila, Mexico: Geological Society of America Bulletin, 102, 593-614.

Miller, H.G., Singh, V., 1994, Potential field tilt - A new concept for location of potential field sources: Journal of Applied Geophysics, 32, 213-217, doi: 10.1016/0926-9851(94)90022-1.

Milligan, P.R., Gunn, P.J., 1997, Enhancement and presentation of airborne geophysical data: AGSO Journal of Australian Geology \& Geophysics. 17(2). 63-75.

Oviedo-Padrón, E.G., Aranda-Gómez, J.J., Chávez-Cabello, G., Molina-Garza, R.S., Iriondo, A., González-Becerra, P.C., Cervantes-Corona, J.A., SolorioMunguía, J.G., 2010, Tectónica de la Sierra Cuesta El Infierno y su posible relación con fallas reactivadas cerca del Levantamiento de Plomosas, Chihuahua, México: Revista Mexicana de Ciencias Geológicas, 27(3), 389-411.

Phillips, J.D., 2000. Locating magnetic contacts: a comparision of the horizontal gradient, analytic signal, and local wavenumber methods, in SEG Technical Program Expanded Abstracts 2000: Society of Exploration Geophysicists, 4 pp, doi: $10.1190 / 1.1816078$

Prian, J.P., Herrera-Galván, J.D., Santos-Montaño, J.d.L., Sánchez-Garrido, E., Arroyo-Ortíz, E., Tarín-Zapata, G., 2000, Carta geológico-minera Hidalgo del Parral G13-5, Chihuahua y Durango, 1:250,000: Pachuca, Servicio Geológico Mexicano, 1 map.

Ramírez-Peña, C.F., 2014, Análisis del contexto tectónico del emplazamiento de intrusivos en el transpaís de la Sierra Madre Oriental: Universidad Autónoma de Nuevo de León, Linares, N.L., M.Sc. Thesis, 160 pp.

Ramírez-Peña, C.F., 2017, Análisis de la deformación progresiva en la zona sur del sector Transversal de Parras y la Saliente de Monterrey, México: Universidad Autónoma de Nuevo de León, Linares, N.L., Mexico, PhD. Thesis, 185 pp.

Ramírez-Peña, C.F., Chávez-Cabello, G., 2017, Age and evolution of thinskinned deformation in Zacatecas, Mexico: Sevier orogeny evidence in the Mexican Fold-Thrust Belt: Journal of South American Earth Sciences, 76, 101-114.

Ramírez, C., Chávez-Cabello, G., Fitz-Díaz, E., Aranda-Gómez, J.J., Sosa, R., 2019, Uplift and syn-orogenic magmatism in the Concepción del Oro Block: A thick skinned (Lamaride-style?) contractional structure in the Mexican Fold an Thrust Belt: Journal of South American Earth Sciences, 93, 242-252, doi: 10.1016/j.jsames.2019.04.012

Ramos-Velázquez, E., Calmus, T., Valencia, V., Iriondo, A., Valencia-Moreno, M., Bellon, H., 2008, U-Pb and ${ }^{40} \mathrm{Ar} /{ }^{39} \mathrm{Ar}$ geochronology of the coastal Sonora batholith: New insights on Laramide continental arc magmatism: Revista Mexicana de Ciencias Geológicas, 25(2), 314-333.

Rogers, C.L., Cserna, Z.de, Tavera-Amezcua, E., Van Vloten, R., Ojeda-Rivera, J., 1961, Reconocimiento geológico y depósitos de fosfatos del norte de Zacatecas y áreas adyacentes en Coahuila, Nuevo León y San Luis Potosí: Boletín del Consejo de Recursos Naturales no Renovables, 56, 322 pp.

Rubatto, D., 2002, Zircon trace element geochemistry: partitioning with garnet and the link between $\mathrm{U}-\mathrm{Pb}$ ages and metamorphism: Chemical Geology, $184,123-138$.

Schulze, G., 1953, Conglomerados terciarios continentales en la Comarca Lagunera de Durango y Coahuila y sus relaciones con los fenómenos ígneos, geomorfológicos y climatológicos: Boletín del Instituto Nacional 
para la Investigación de los Recursos Minerales, 30, 52.

Sedlock, R.L., Ortega-Gutiérrez F., Speed R.C., 1993, Tectonostratigraphic terranes and tectonic evolution of Mexico: Geological Society of America, Special Paper, 278, 153 pp.

Soegaard, K., Ye, H., Halik, N., Daniels, A.T., Arney, J., Garrick, S., 2003, Stratigraphic evolution of Latest Cretaceous to early Tertiary Difunta foreland basin in northeast Mexico: Influence of salt withdrawal on tectonically induced subsidence by the Sierra Madre Oriental fold and thrust belt, in Bartolini, C., Buffler, R.T., Blickwede, J. (eds.), The CircumGulf of Mexico and the Caribbean: Hydrocarbon habitats, basin formation, and plate tectonics: AAPG Memoir 79, 364-394.

Solari, L.A., Gómez-Tuena, A., Bernal, J.P., Pérez-Arvizu, O., Tanner, M., 2010, $\mathrm{U}-\mathrm{Pb}$ zircon geochronology with integrated LA-ICP-MS microanalytical workstation: Achievements in precision and accuracy: Geostandards and Geoanalytical Research, 34, 5-18.

Solari, L.A., González-León, C.M., Ortega-Obregón, C., Valencia-Moreno, M., Rascón-Heimpel, M.A., 2018, The Proterozoic of NW Mexico revisited: $\mathrm{U}-\mathrm{Pb}$ geochronology and $\mathrm{Hf}$ isotopes of Sonoran rocks and their tectonic implications: International Journal or Earth Sciences, 107, 845-861, doi:10.1093/ajen/nqy030

Spencer, C.J., Kirkland, C.L., Taylor, R.J., 2016, Strategies towards statistically robust interpretations of in situ U-Pb zircon geochronology: Geoscience Frontiers, 7(4), 581-589.

Sklyarov, E.V., Fedorvskii, V.S., 2006, Magma mingling: Tectonic and Geodynamic implications: Geotectonics 40(2), 47-64
Talwani, M., Heirtzler, J.R., 1964, Computation of magnetic anomalies caused by two-dimensional structures of arbitrary shape in Computers in the mineral industries, Part1: Stanford University Publications, Geological Sciences, 9, 464-480.

Tardy, M., 1980, Contribution a l'etude geologique de la Sierra Madre Orientale du Mexique: Département de Géotectonique de l'Université Pierre et Marie Curie à Paris et Département des Sciences de la Terre de l'Université de Savoie à Chambéry, $\mathrm{PhD}$. Thesis, $459 \mathrm{pp}$.

Troll, V.R., Donaldson, C.H., Emeleus, C.H., 2004, Pre-eruptive magma mixing in ash-flow deposits in the Tertiary Rum Igneous Centre, Scotland: Contributions to Mineral Petrology, 147, 722-739.

Valencia-Moreno, M., Camprubí í Cano, A., Ochoa-Landín, L., Calmus, T., Mendívil-Quijada, H., 2017, Latest Cretaceous-early Paleogene "boom" of porphyry $\mathrm{Cu}$ mineralization associated with the Laramide magmatic arc of Mexico: Ore Geology Reviews, 81, 1113-1124.

Manuscript received: march 29, 2019

Corrected manuscript received: august 9, 2019

Manuscript accepted: august 13, 2019 